\title{
SULFATE-RICH EOLIAN AND WET INTERDUNE DEPOSITS, EREBUS CRATER, MERIDIANI PLANUM, MARS
}

\author{
JOANNAH M. METZ, ${ }^{1}$ JOHN P. GROTZINGER, ${ }^{1}$ DAVID M. RUBIN, ${ }^{2}$ KEVIN W. LEWIS, ${ }^{1}$ STEVEN W. SQUYRES, ${ }^{3}$ AND JAMES F. BELL, III ${ }^{3}$ \\ ${ }^{1}$ Division of Geological and Planetary Sciences, Caltech, Pasadena California 91125, U.S.A. \\ ${ }^{2}$ U.S. Geological Survey, USGS Pacific Science Center, 400 Natural Bridges Drive, Santa Cruz, California 95060, U.S.A. \\ ${ }^{3}$ Department of Astronomy, Space Sciences Building, Cornell University, Ithaca, New York 14853, U.S.A. \\ e-mail: joannah@caltech.edu
}

\begin{abstract}
This study investigates three bedrock exposures at Erebus crater, an $\sim 300 \mathrm{~m}$ diameter crater approximately $4 \mathrm{~km}$ south of Endurance crater on Mars. These outcrops, called Olympia, Payson, and Yavapai, provide additional evidence in support of the dune-interdune model proposed for the formation of the deposits at the Opportunity landing site in Meridiani Planum. There is evidence for greater involvement of liquid water in the Olympia outcrop exposures than was observed in Eagle or Endurance craters. The Olympia outcrop likely formed in a wet interdune and sand sheet environment. The facies observed within the Payson outcrop, which is likely stratigraphically above the Olympia outcrop, indicate that it was deposited in a damp-wet interdune, sand sheet, and eolian dune environment. The Yavapai outcrop, which likely stratigraphically overlies the Payson outcrop, indicates that it was deposited in primarily a sand sheet environment and also potentially in an eolian dune environment. These three outcrop exposures may indicate an overall drying-upward trend spanning the stratigraphic section from its base at the Olympia outcrop to its top at the Yavapai outcrop. This contrasts with the wetting-upward trend seen in Endurance and Eagle craters. Thus, the series of outcrops seen at Meridiani by Opportunity may constitute a full climatic cycle, evolving from dry to wet to dry conditions.
\end{abstract}

\section{INTRODUCTION}

The development, testing, and refinement of facies models lies at the core of the analysis of sedimentary rocks on Earth. Multiple outcrop exposures or well information create the basis for this approach, whose application has great relevance for the interpretation of sedimentary rocks on Mars. At Meridiani Planum, randomly distributed impact craters provide spatially separated outcrops that can be interrogated for information related to depositional processes. The results obtained for each crater can be used to evaluate developing facies models.

The Mars Exploration Rover (MER) Opportunity has investigated several bedrock exposures in craters in Meridiani Planum. Facies models developed by studying outcrops in Eagle and Endurance craters create a framework to which each new crater can be compared. The purpose of this study was to test and refine existing models proposed for the formation of the Meridiani bedrock by investigating new outcrop exposures at Erebus crater, an 300-m-diameter crater approximately $4 \mathrm{~km}$ south of Endurance crater (Fig. 1A). Erebus crater is a large simple crater, and Mars Global Surveyor-Mars Orbiter Camera stereo data and Mars Orbiter Laser Altimetry data suggest that the land surface surrounding Erebus crater is about $10-15 \mathrm{~m}$ higher in elevation than Endurance crater. Assuming the bedrock to be approximately flat lying, this implies that the rocks at Erebus may be at a slightly higher stratigraphic level than Endurance. The outcrops examined at Erebus are concentrated along the rim of the crater and have been informally named Olympia, Payson, and Yavapai (Fig. 1B).

The sulfate-rich bedrock exposed along the walls at Eagle and Endurance craters has been interpreted by the MER team to have been deposited in an eolian dune-interdune environment (Squyres et al. 2004; Grotzinger et al. 2005; Grotzinger et al. 2006). This interpretation of the outcrops has been challenged by McCollom and Hynek (2005) and Knauth et al. (2005), who suggested that volcanic or impact-related sedimentation was responsible for the deposition of the Meridiani bedrock. These strongly contrasting models make specific sedimentologic predictions for Meridiani bedrock exposures; the current study documents an important new locality that provides data to help test these models. All of the observations point to a dune-interdune scenario. This allows consideration of potential climatic influences, which is a major concern for the environmental evolution of Mars.

\section{REGIONAL SETTING}

Erebus crater is located in the Terra Meridiani region of Mars. The oldest rocks constitute a Noachian-age basal unit that has been extensively dissected by channel systems (Arvidson et al. 2003). Lying disconformably on top of the dissected cratered terrain is a widespread, partially eroded, layered complex consisting of several light-toned stratigraphic units. The layered complex ("etched terrain") has a variable morphology which includes polygonal ground separated by ridges and valleys and accumulations of strata which have been eroded into a variety of landforms (Arvidson et al. 2003). These essentially flat-lying strata extend laterally for distances in excess of $100 \mathrm{~km}$. Erosional features within the etched terrain indicate that several hundred meters have been stripped from this deposit (Arvidson et al. 2003). The etched terrain covers $2.3 \times 10^{5} \mathrm{~km}^{2}$ and is at least $500 \mathrm{~m}$ thick (Hynek 2004). The strata in the etched terrain are inferred to be lithified sedimentary rock, 


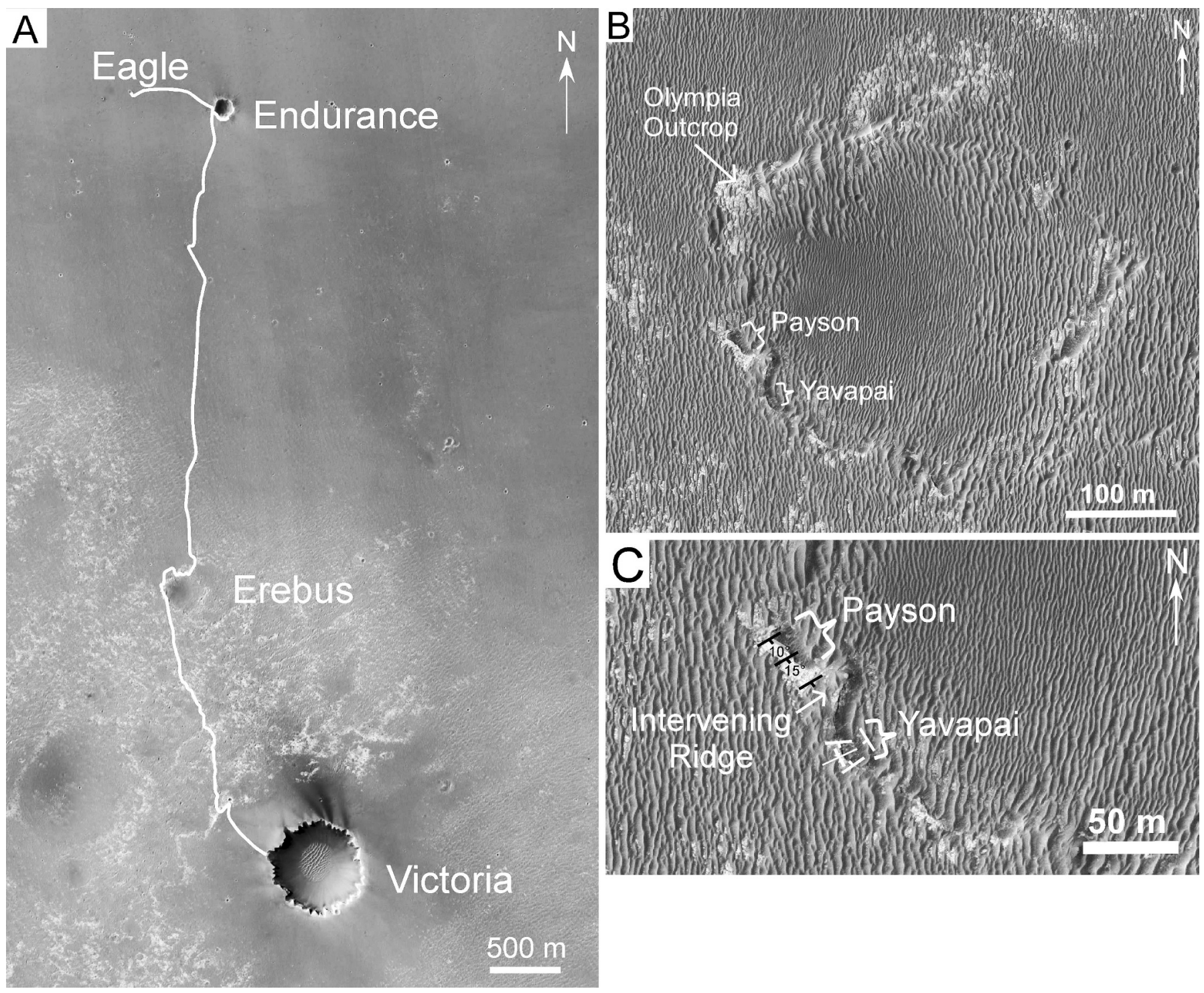

FIG. 1.-Subscenes from HiRISE image PSP_001414_1780, which was acquired on November 14, 2006 (Mars northern summer). The image was taken at the local Mars time of 3:26 p.m., and the scene was illuminated from the west at a solar incidence angle of $54^{\circ}$. A) HiRISE image showing rover traverse path in red. The rover drove from Eagle crater east to Endurance crater, and then drove $4 \mathrm{~km}$ south to Erebus crater en route to Victoria crater. B) Erebus crater with locations of the Olympia Outcrop, Payson, and Yavapai marked. C) Close-up view of the western margin of Erebus crater showing the strike and dip of bedding in the Payson, Intervening Ridge, and Yavapai outcrops. The trend of the axis of the potential syncline at Yavapai is also indicated.

because they maintain nearly vertical cliffs and have high thermal inertia (Edgett and Malin 2002; Arvidson et al. 2006).

Strata of the etched terrain are capped by hematite-bearing plains which are characterized by a smooth morphology and dark tone (Arvidson et al. 2003; Arvidson et al. 2006); these materials have locally been reworked into a variety of eolian bedforms including dunes and granule ripples (Jerolmack et al. 2006). Exposure of light-toned bedrock of the etched terrain can be seen in the interdune areas. The northern part of the Meridiani region is covered by a mantle whose thickness is $\sim 10 \mathrm{~m}$, thickening to $30 \mathrm{~m}$ toward the north (Arvidson et al. 2003).

Opportunity has examined the extremely flat plains and several craters within the hematite-bearing plains unit in Terra Meridiani. The bedrock exposures near and within Eagle, Endurance, and Erebus craters have allowed detailed examination of the layers in the lower part of the topmost strata in the etched terrain. Due to differential erosion, the strata exposed at the upper surface of the etched terrain vary considerably in age. A framework for interpretation of the bedrock exposures investigated by Opportunity was outlined in Grotzinger et al. (2005).

Endurance and Eagle craters (Fig. 1A) expose a combined stratigraphic thickness of $7 \mathrm{~m}$ of sedimentary rocks called the Burns formation (Grotzinger et al. 2005). These outcrops are composed dominantly of fineto medium-grained sandstones. Geochemical and mineralogic data show that the grains are composed of $50 \%$ fine-grained siliciclastic materials derived from the weathering of basaltic rock, $40 \%$ sulfate minerals, and 10\% hematite (Squyres et al. 2004; Clark et al. 2005). Exposed rocks are soft, as revealed through grinding using the rock abrasion tool (RAT); they have a resistance to abrasion similar to talc (Arvidson et al. 2004). Most outcrops are laminated and formed of well-rounded and well-sorted grains, bound together with intergranular cements (Grotzinger et al. 2005). Mineralogical and geochemical data support sedimentologic observations of evaporative processes and indicate the presence of abundant sulfate minerals, including jarosite and probable calcium and magnesium sulfates, 
in addition to later remobilization of evaporite mineral phases (Clark et al. 2005; McLennan et al. 2005).

The Burns formation at Endurance crater can be subdivided into lower, middle, and upper units. The lower unit contains large-scale cross-bedded sandstone and is interpreted to represent an eolian dune facies. The middle unit is dominated by several meters of planar-laminated to lowangle cross-stratified sandstone with an overprint of nodular recrystallization and is interpreted as representative of an eolian sand sheet. The upper unit contains planar lamination, low-angle stratification, and small-scale cross-stratification in sets, including rare small-scale trough cross-lamination. This unit is interpreted as having been deposited in a mixed eolian sand sheet and interdune environment (Grotzinger et al. 2005). According to this model, the sequence shows a wetting-upward succession and records a progressive increase in the influence of groundwater and ultimately surface water on deposition and subsequent diagenesis (Grotzinger et al. 2005). Centimeter-scale trough crosslamination in the upper unit is indicative of sediment transport in shallow subaqueous flows with current velocities of a few tens of centimeters per second (Grotzinger et al. 2005). These flows most likely resulted from the flooding of interdune-playa surfaces.

\section{STRATIGRAPHIC FRAMEWORK FOR EREBUS CRATER}

\section{Methods}

Structural attitudes were obtained using planar fits to bedding seen in Pancam images of the Payson outcrop. Linear segments were traced out along well-exposed layers. Only layers with some natural curvature in the horizontal direction were used in order to provide accurate constraints on the three-dimensional geometry of the layer. This was done because linear segments do not provide any information on the direction perpendicular to the line. We employed the method presented in Squyres et al. (2007) and Lewis et al. (2008b), which uses principal component analysis to ensure the layers used are well fitted by a plane. Where sufficient outcrop curvature was not present, apparent dips were used.

The stratigraphy was mapped by visual tracing and correlation of key beds across the outcrop. Breaks due to lack of outcrop and possible small fault offsets were accounted for, and composite stratigraphic thicknesses were estimated by using key beds to link different parts of the outcrop.

\section{RESULTS}

\section{Structure}

Opportunity obtained images of Erebus crater from sols 647 to 759 . The bedrock exposures in Erebus crater include a large expanse called the Olympia outcrop (Fig. 1B). The outcrop appears as a relatively flat pavement due to recent eolian abrasion. The structural dips of the rocks at the Olympia outcrop are up to $\sim 15-30^{\circ}$, with variable strike, possibly caused by the crater-forming impact that rotated individual rocks or sections of rock (Grotzinger et al. 2006). Correlations between individual blocks at Olympia generally were not possible. Two, more prominent, outcrops are located farther south along the western rim of Erebus crater. These more prominent outcrops feature $\sim 1$-m-high vertical exposures of outcrop that extend for $\sim 80 \mathrm{~m}$ from the north end of the northern outcrop ("Payson") to the south end of the southern outcrop ("Yavapai") (Fig. 1B). There is a small ridge separating the two outcrops (Fig. 1C). The stratigraphic relationship between Payson and Yavapai cannot be resolved with certainty, but from the images acquired it appears that the bedding continues beyond Payson across the intervening ridge with similar dips, and so Yavapai is likely stratigraphically higher than Payson. Together, these two outcrops represent approximately $10 \mathrm{~m}$ of stratigraphic section.

The northern and southern outcrops were imaged between sols 742 and 758, with Payson imaged from three different positions and Yavapai from two positions. The dip of the Payson strata ranges between 10 and $15^{\circ}$ and all of the layers strike in a SE-NW direction (Fig. 1C). The Payson outcrop is approximately $31 \mathrm{~m}$ long and ranges in height from $0.75 \mathrm{~m}$ to $1.6 \mathrm{~m}$. The total stratigraphic thickness represented by Payson is $4.85 \mathrm{~m}$. A fracture cuts across the northern end of the outcrop (Fig. 2A). The bedding at the northern end of the outcrop dips at $\sim 10^{\circ}$ to the SE. Approximately $10 \mathrm{~m}$ along from the north end of the outcrop exposure at Payson, there is a change in the bedding dip (Fig. 2A). The apparent dips become steeper south of this area, with dips measuring around $15^{\circ}$ to the SE. Since Erebus crater is a highly eroded simple crater whose plan view departs significantly from circular (Melosh 1989), it is likely that the current walls are the result of a large amount of erosion of the original rim walls. The current walls are likely far removed from the original rim, and also potentially below the original flanks of the crater. The outcrop dips are also not directed radially away from the crater, as would be expected if they were the result of the crater-forming impact. Erebus crater is superposed on an older crater, Terra Nova, so the dips observed at Erebus may potentially be related to the combined deformation from both impacts. However, the observed dips at Erebus crater also do not coincide with the expected radial outward dips from the Terra Nova impact. Terra Nova is also a heavily eroded crater, and so as described earlier for Erebus, the current exposures are probably far removed from the original walls of Terra Nova. Thus, the dips observed at Erebus may have originated from a complicated interaction of the deformation from both the Erebus and Terra Nova impacts.

The Yavapai outcrop is approximately $30 \mathrm{~m}$ in length and is separated from the Payson outcrop by about $20 \mathrm{~m}$. Only the northernmost $6 \mathrm{~m}$ of the outcrop was imaged in enough detail to characterize the diversity of sedimentary structures. The section of the Yavapai outcrop for which images were acquired can be separated into two units (Fig. 3). The lower unit has approximately $0.8 \mathrm{~m}$ of vertical relief, and the upper unit has between 1.5 to $2.5 \mathrm{~m}$ of vertical relief; they are separated by $\sim 5 \mathrm{~m}$ of areal soil cover. Yavapai strata define either (1) an open syncline, with the fold axis trending roughly east-west and plunging into the outcrop (Figs. 1C, 4A) or (2) a set of large-scale trough-shaped cross-strata with the variable dip directions due to exposure of cross-bed layers on both sides of the trough bedform (Figs. 1C, 4B). The total stratigraphic thickness represented by the Yavapai outcrop is $5.15 \mathrm{~m}$.

\section{FACIES AND DEPOSITIONAL PROCESSES}

All of the rocks in the Olympia, Payson, and Yavapai outcrops are interpreted to be sandstones on the basis of the predominance of clastic textures. This is supported by Microscopic Imager (MI) images of the Olympia outcrop, located $50 \mathrm{~m}$ north of Payson, which show predominantly medium-sand-size grains (Fig. 5). MI images were not obtained for the Payson or Yavapai outcrops, but grains are below the limit of the resolution of the Pancam images.

The composition of the rock "Ted" (Fig. 6) at Olympia is similar to that observed at Endurance and Eagle craters (Knoll et al. 2008) and the rock is similarly interpreted to have been derived from reworked, siliciclastic-rich evaporites. The presence of centimeter-scale lamination in many of the facies makes it likely that these deposits accumulated as the result of bedload traction transport of sand-size particles. The facies observed at Olympia, Payson, and Yavapai include mottled sandstone, syn-sedimentary deformed sandstone, wavy laminated to small-scale trough crosslaminated sandstone, and planar-stratified to low-angle-stratified sandstone. There are zones of intense recrystallization where the deposits appear massive, but there is also generally evidence for palimpsest layering, indicating that the original deposits were not massive.

\section{Mottled Sandstone}

There are several occurrences in the Payson outcrop of a mottled and disrupted texture that is poorly stratified to massive. This facies appears 

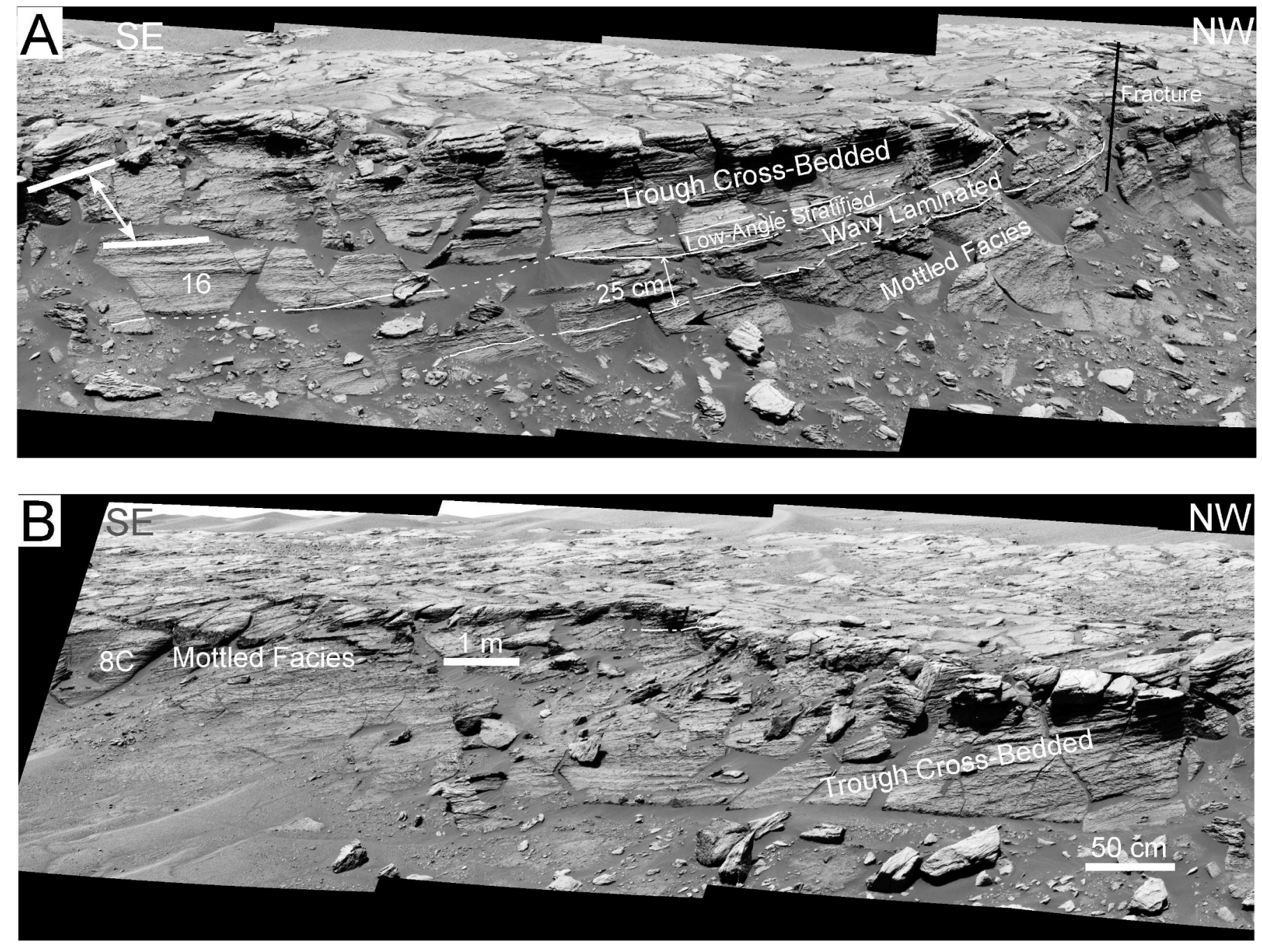

FIG. 2.-The northern two-thirds of the Payson outcrop shown as two overlapping panels. The facies transitions are marked by white lines. Solid lines are drawn where the transitions are clearly defined, and dashed lines are drawn where the transitions are inferred or partially obscured. These images were taken by the Pancam on sol 749 with the $430 \mathrm{~nm}$ filter. A) Northernmost section of Payson. A fracture, likely formed during formation of Erebus crater, is marked by a black line. The mottled facies, wavy-laminated facies, low-angle stratified facies, and trough cross-bedded facies are marked. The location of Figure 16 is indicated. The two thick white lines and the white arrow indicate the area where the dip of the outcrop bedding increases from $\sim 10^{\circ}$ to $\sim 15^{\circ}$, measured relative to a horizontal surface. B) The middle section of the Payson outcrop, showing the trough cross-bedded and mottled facies. The location of Figure $8 \mathrm{C}$ is indicated.

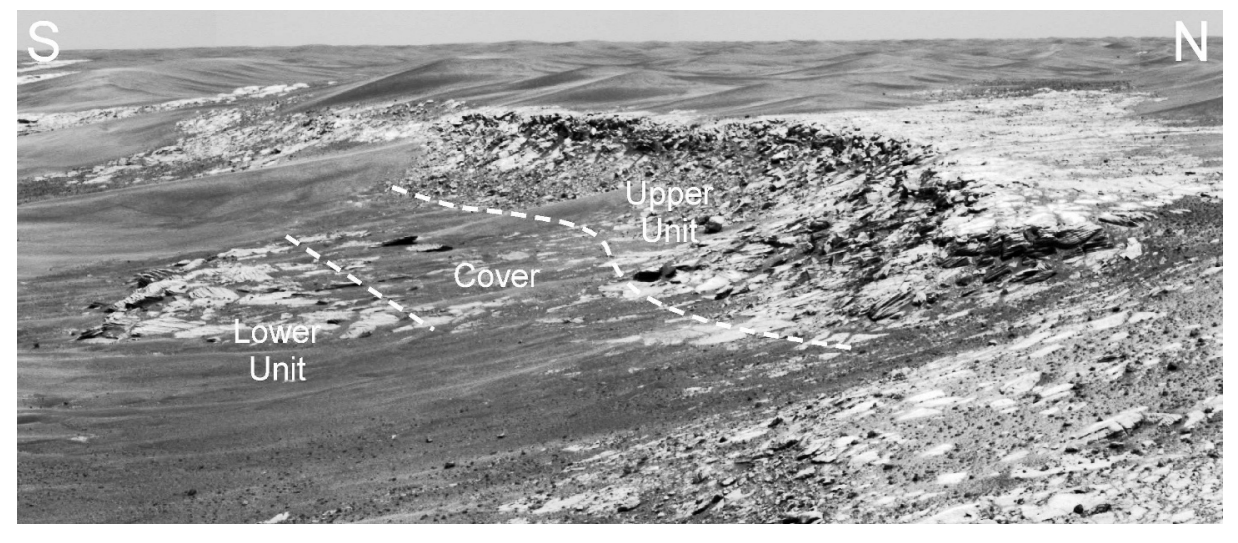

FIG. 3.-The Yavapai outcrop, showing the locations of the lower and upper units and the interval of cover between them. Dashed white lines indicate the approximate locations of the unit boundaries, in this case defined by limits of exposure. Navcam image acquired on sol 755. 


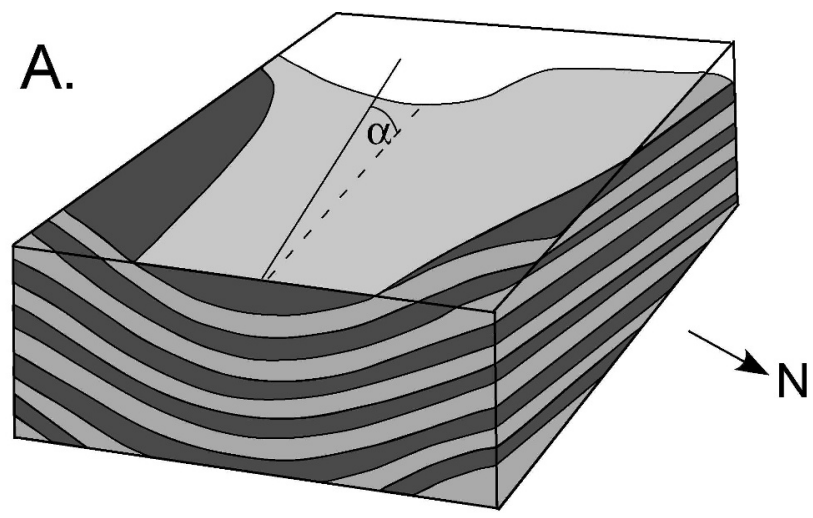

B.

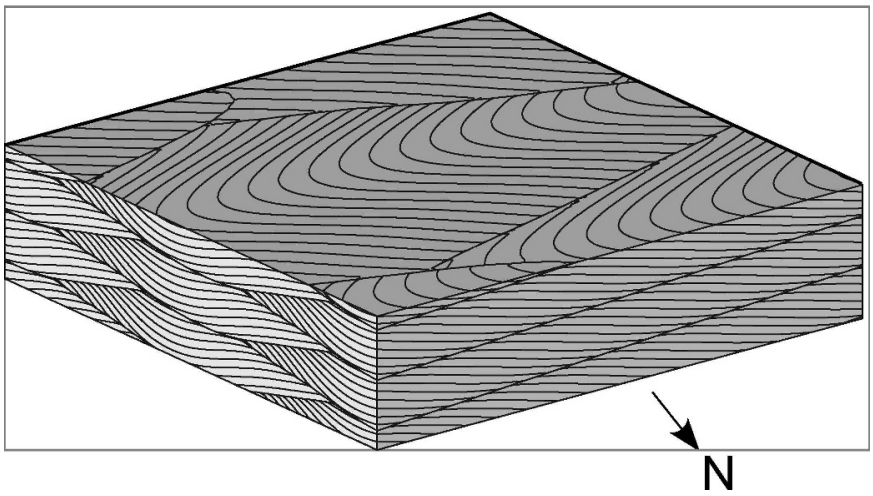

Fig. 4.-A) Hypothetical geometry of beds in the upper unit of the Yavapai outcrop if they form a syncline. $\alpha$ is the plunge of the fold axis. B) Hypothetical geometry of the beds in the upper unit of Yavapai if they represent opposite sides of large trough-shaped sets of cross-beds.

in both the lower unit and the upper unit at Payson (Figs. 2, 7, 8). Beds in the mottled facies in the lower unit are $\sim 4-6 \mathrm{~cm}$ thick and show palimpsest millimeter-scale lamination in some areas. Although the Meridiani rocks are classified as sandstones because of their primary

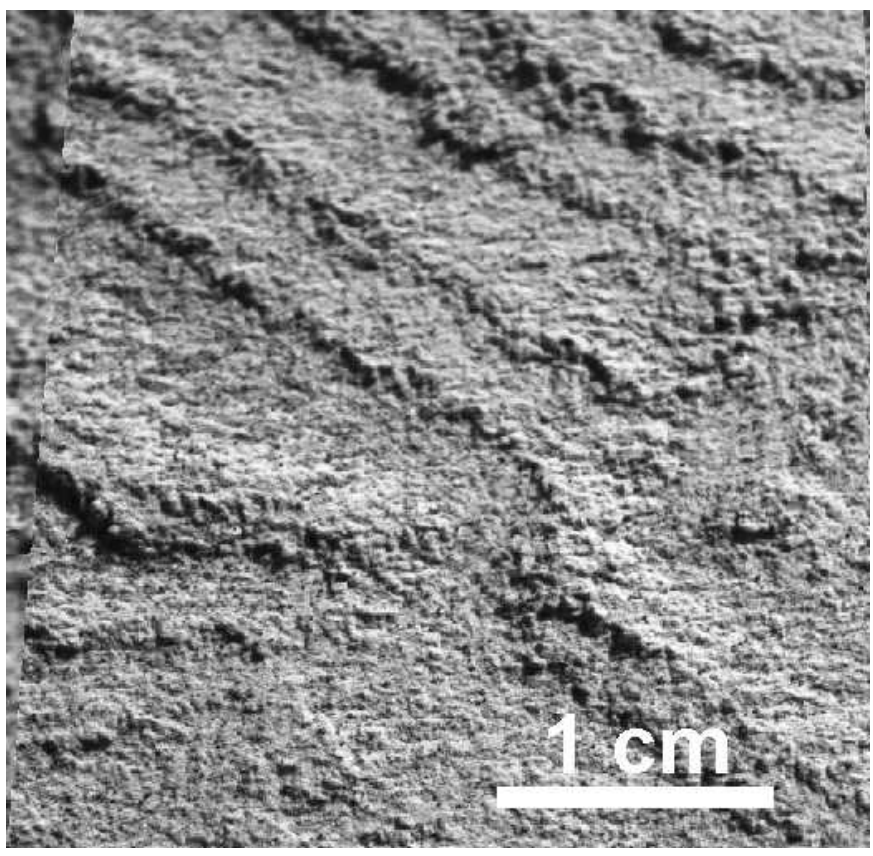

FIG. 5.-Microscopic imager photograph of the rock lower Overgaard showing the typical grain sizes and sorting within the Olympia outcrop. Grains are predominantly of medium sand size, with interlocking textures due to cementation. Image acquired on sol 708 .

texture, their very unusual composition and the highly labile nature of the mineralogy lead to textures not commonly seen in sandstones (McLennan et al. 2005; Tosca et al. 2008). Therefore, we must turn to chemical sedimentary rocks for potential analogs. Mottling occurs in terrestrial carbonate rocks when part of the limestone is diagenetically replaced by dolomite, causing a difference in composition and crystallinity. This can result in obliteration of primary depositional stratification (Beales 1972; Bullen and Sibley 1984). Though the rock composition for Payson is very different from these well-documented terrestrial carbonates, we envision a similar process whereby the appearance of a mottled facies at Payson is likely a diagenetic overprint and not a primary depositional facies. The intensity of the proposed recrystallization varies both horizontally and

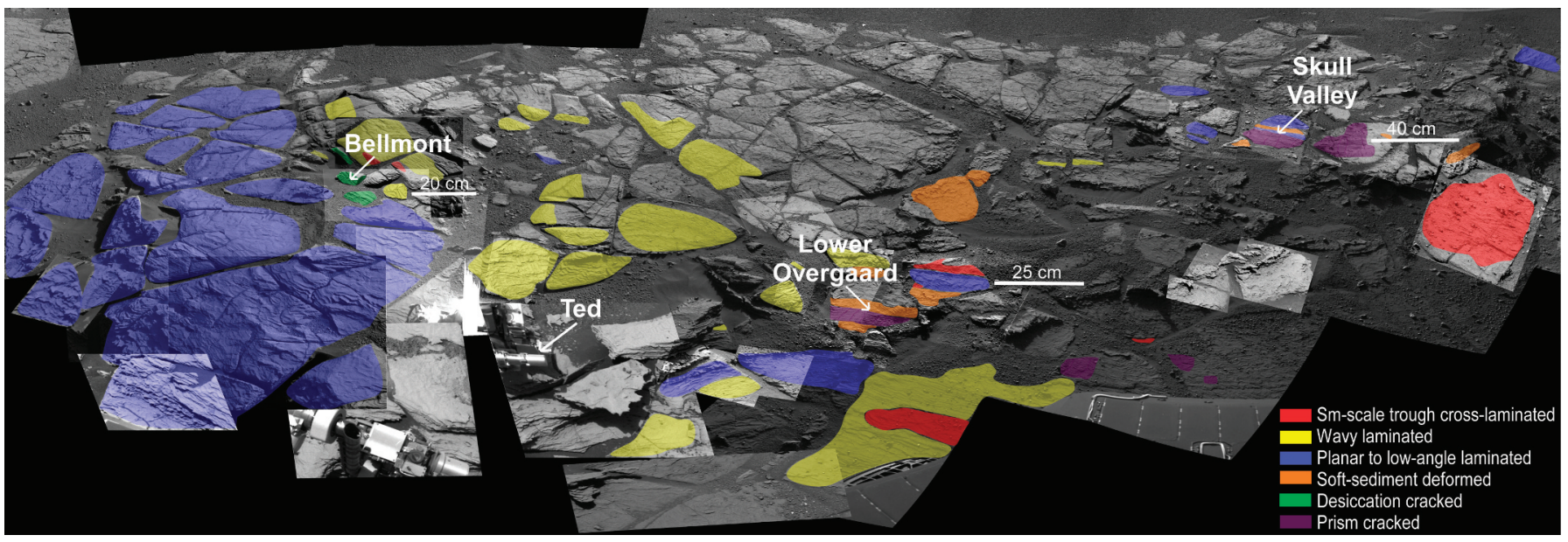

FIG. 6.-Distribution of facies at the Olympia outcrop. Where facies could be determined they are marked on the outcrop by the indicated colors. Rocks discussed in this paper (Bellemont, lower Overgaard, and Skull Valley) are identified. Correlation of facies is severely limited due to impact-related brecciation and block rotation. These images were acquired between sols 652 and 694 with Pancam's 482 nm filter. 


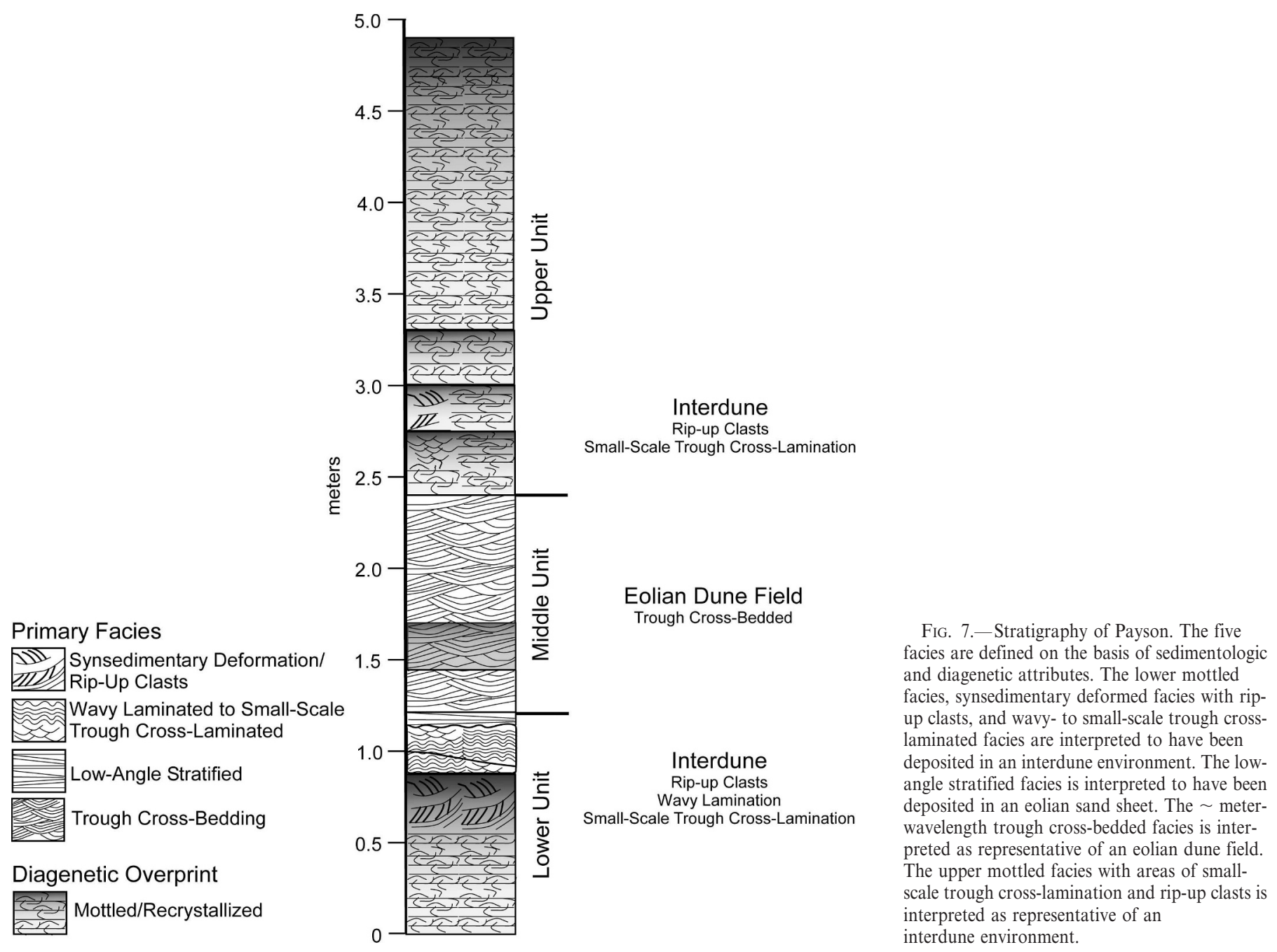

vertically in this facies in the lower unit of Payson (Fig. 8A i-iv). Where stratification is visible in the mottled facies in the lower unit, synsedimentary deformation and possible rip-up clasts also are visible. The upper unit of Payson is composed entirely of the mottled facies which extends to the top of the outcrop (Figs. 2B, 7, 8C). In this area, where hints of the original stratification remain, it appears to be wavy- or smallscale trough cross-laminated (Fig. 8C).

Recrystallization could have occurred in the phreatic or capillary zone of a paleo-water table. Groundwater in contact with a sulfate evaporite deposit readily dissolves the rock unless the water is already saturated with respect to the specific sulfate phase (Johnson 2005; Tosca et al. 2005). Tosca et al. (2005) have modeled the evaporation of fluids derived from acid weathering of Martian basalt, and their model suggests that $\mathrm{Mg}, \mathrm{Ca}$, and $\mathrm{Fe}$ sulfates should be produced. They also calculated the solubility of these evaporite minerals under diagenetic conditions that were likely in Meridiani Planum and found that epsomite (Mg sulfate) and melanterite (Fe sulfate) were the most soluble but gypsum took much longer to dissolve (Tosca et al. 2005). Since the rock in the mottled facies does not appear to have an increased porosity on a scale visible to the Pancam (minimum size of features that can be resolved is several millimeters), any fluid responsible for the diagenetic alteration must have been a brine saturated or very close to saturated with respect to the chemical composition of the rocks (Tosca et al. 2005).

\section{Synsedimentary Deformed Sandstone}

Soft-Sediment Deformation.-Soft-sediment deformation features were observed at Eagle crater (see fig. 13D in Grotzinger et al. 2005) and are abundant in the Olympia outcrop. At both locations such features are closely associated with the small-scale trough cross-laminated facies and synsedimentary shrinkage cracks. All observed features are of small scale, and consist of irregular zones of crude bedding that are laterally adjacent to cracks, and zones of bedding-parallel shortening and folding. These are illustrated in two rocks in the Olympia outcrop: in the middle and uppers parts of Skull Valley, and in the upper part of lower Overgaard (Fig. 9).

The upper part of lower Overgaard contains deformed strata in which a small-scale fold along the right edge of the field of view of the rock nucleates and grows above a boundary that approximately coincides with the upper limit of underlying synsedimentary cracks (Fig. 9A). Strata that define this fold pass laterally (to the left) into other deformed strata. Notably, all of this deformation does not seem to affect the lower (cracked) part of lower Overgaard, suggesting bedding-parallel shortening above a distinct surface of detachment. However, the lowermost part of lower Overgaard also seems to contain a zone of folding; here, folds seem to be onlapped by younger laminae containing the planar cracks described in Grotzinger et al. (2006). 



FIG. 8.-A) Section of the Payson outcrop showing the locations of Figures 8B, 11A, and 12. The lateral and vertical variation in the extent of recrystallization can be seen; the lateral variation is particularly noticeable along the stratigraphic horizon marked by the horizontal white lines. Boxes i-iv show the areas outlined in the black boxes in more detail. In box i, the original stratification is well preserved, but some of the original texture is lost farther along the same layer as shown in box ii. In box iii the recrystallization has been more intense, with much of the original stratification lost, while farther to the right in box iv the original stratification is almost completely lost. These images illustrate that although some areas of the outcrop may appear massive, they were all originally stratified at the centimeter-scale. Pancam image acquired on sol 749 with the $430 \mathrm{~nm}$ filter. B) Close-up view of the mottled area below and including box iv. The original stratification is nearly absent due to recrystallization. C) Close-up view of the upper mottled facies in the area indicated in Figure 2B. The mottled appearance of this area is interpreted to be the result of recrystallization. This palimpsest lamination suggests that the original stratification was likely wavy-laminated to small-scale trough cross-laminated. Pancam image acquired on sol 753 with the $430 \mathrm{~nm}$ filter.
Skull Valley contains a distinct zone, localized near the upper part of the rock, which likely also involves soft-sediment deformation (Fig. 9B). At the upper left margin of the rock a cracked lamina is portioned into three pieces which are offset. The right-hand fragment is curled upward. At this stratigraphic level, in the center of the rock, all texture is lost and the bedding is massive. Along the right margin of the rock this massive zone shows evidence of projecting upward across laminae which are also deformed in an upward direction. Underlying laminae are relatively intact, which suggests that sediments in the massive zone were fluid enough to penetrate bedding. By analogy to similar terrestrial features, this could have involved flow across upward-directed pressure gradients induced by early compaction of differentially permeable sediments.

Shrinkage Cracks.-Possible shrinkage cracks are common in the Olympia outcrop. These cracks have been identified in the rock Bellemont in a cross-sectional view where they are observed to taper downward in a v-shape (Fig. 10). They cut perpendicularly across several sedimentary layers and have also been infilled with sediment. Putative cracks appear to start at several levels, are up to $6 \mathrm{~mm}$ wide at their surface of initiation, and taper downward to 1-2 $\mathrm{mm}$ at their base over a stratigraphic distance of 5-8 mm (3-4 laminae). MI data show that cracks are filled with sediment that is texturally similar to laminae which are cracked. Most cracks are oriented perpendicular to bedding, though some crosscut bedding at an angle and may show compaction related deformation.
The rapid taper and large amount of shrinkage which caused these cracks is unusual for terrestrial sandstones; here it is possibly due to the unusual mineralogy of the grains. The original grains were not nonporous silicate grains, such as olivine or pyroxene, but probably a lightly cemented mudstone (McLennan et al. 2005). Geochemical measurements and modeling suggest that the grains are magnesium sulfates (McLennan et al. 2005). If the grains were deposited as a hydrated magnesium sulfate such as epsomite (with seven waters of hydration), then dehydration may have caused the sediments to shrink enough to cause these cracks. However, this is speculative due to the uncertain timing of dehydration which may have occurred over longer time scales. More likely, shrinkage was due to a dehydration of the pore fluids, which would have existed in the lightly cemented grains as well as between grains.

Prism cracks, which are polygonal networks of cracks that form normal to bedding and break the sediment into vertical prisms (Fischer 1964), were also identified in the Olympia outcrop. These occurrences were described in Grotzinger et al. (2006) and are interpreted as shrinkage cracks formed during desiccation of damp sediments.

The columnar structure of the prism cracks is maintained by repeated cycles of wetting and drying, with cracking over the same polygonal cracks occurring after deposition of new lamina (Demicco and Hardie 1994).

Rip-Up Clasts.-The mottled facies in the lower unit of Payson contains possible evidence of brittle synsedimentary deformation, 


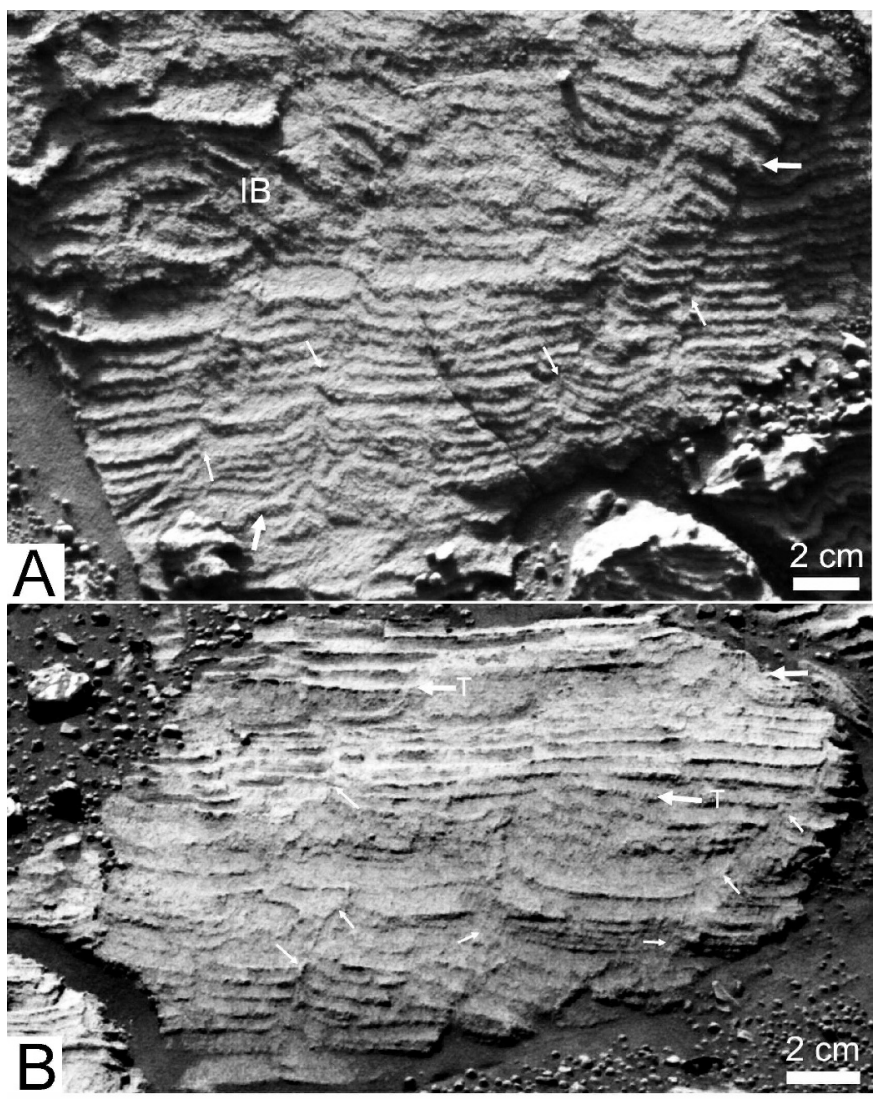

FIG. 9.-A) Lower Overgaard. Two cracks at the right margin of Overgaard are reactivated, in the upper part of the rock, to form a soft-sediment deformation fold (upper large arrow). To the left of the fold, in equivalent strata, note generally incoherent bedding (labeled "IB") suggesting soft-sediment deformation. Also note soft-sediment-related folding in lowermost part of rock (lower large arrow); fold is onlapped by overlying laminae. This super-resolution image was acquired on Sol 698 at 16:32:03 LTST using Pancam's 482 nanometer filter, sequence id p2572. B) Skull Valley. Numerous penecontemporaneous cracks (small arrows) crosscut lamination, some oblique to bedding. Note zone of soft-sediment deformation in upper right corner of rock (large arrow in upper right). Note truncation of upward-deflected laminae along discrete bedding planes in center and upper parts of rock (large arrows with T). This super-resolution image was acquired on Sol 713 at 13:48:35 LTST using Pancam's 482 nanometer filter, sequence id p2589.

including potential rip-up clasts (Fig. 11). The rip-up clasts are interpreted to represent chips and pieces of former lamination that were cemented early and then broken up and reworked. A consistent flow direction results in clast imbrication; several imbricated clasts are seen in the Payson outcrop, and they indicate a flow direction from north to south.

Some of the putative rip-up clasts seen in Payson appear to have still been somewhat soft when they were ripped up, since they appear curved or deformed (near black arrow in Fig. 11A). Others seem to have undergone brittle deformation, because they were already partially lithified; therefore, these clasts remained flat (white arrow in Fig. 11A.). Evidence to support the supposition that these are rip-up clasts includes the fact that the thickness of the putative rip-up clasts is the same as the intact lamination above and below the deformed area. Also, some of the pieces appear to have been laminae that were deformed and then broken off from more continuous lamination at the same stratigraphic level. Such syndepositional deformation and rip-up structures are often found in wet interdune environments (Mountney and Thompson 2002).

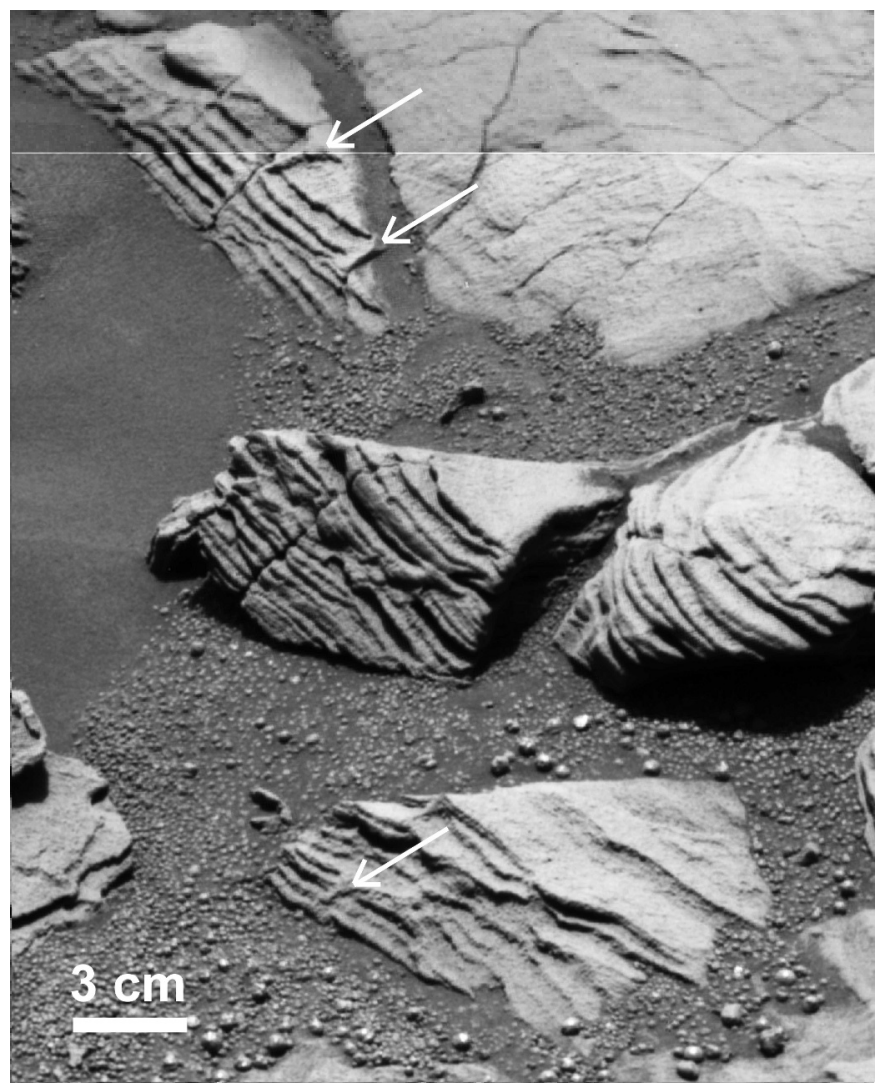

FIG. 10.- Possible shrinkage cracks in the rock Bellemont. White arrows highlight the locations of the cracks. Note how cracks taper downward in a vshape cutting perpendicularly across several laminae. This super-resolution image was acquired on sol 665 with the $482 \mathrm{~nm}$ filter.

It is possible that these features are related to later strain, associated with the impact-forming deformation event. However, these features are developed only in a few specific beds. Furthermore, they have not been observed in any other outcrops, including Eagle and Endurance craters where impact also occurred. Such penetrative strain would be expected to be ubiquitous, yet these features are rare. Therefore, their origin due to impact seems unlikely.

\section{Small-Scale Trough Cross-Laminated to Wavy-Laminated Sandstone}

Possible centimeter-scale trough cross-lamination occurs in some beds near the south end of Payson. The potential small-scale troughs are not well exposed, and the resolution of the images in the areas with the potential troughs is not sufficient to identify them unambiguously. The Olympia outcrop, however, contains several areas that show well-exposed small-scale trough cross-lamination, described in Squyres et al. (2006) and Grotzinger et al. (2006). Small-scale trough cross-lamination (also known as festoon cross-lamination) is formed by migration of three-dimensional ripple bedforms with sinuous crestlines that climb at generally positive angles in flowing water (Rubin 1987). The bounding surfaces scoured by three-dimensional bedforms tend to be trough-shaped. This type of crosslamination at this scale is common in deposits of subaqueous ripples (Hunter 1977b; Winston 1978) but very rare in deposits of eolian impact ripples. Eolian ripples typically have straight crestlines and uniform spacing, and therefore deposit thin tabular beds; these deposits are typically inversely graded rather than cross-laminated (Hunter 1977b).

Wavy-laminated strata occur in the lower unit of the Payson stratigraphy, between $0.9 \mathrm{~m}$ and $1.2 \mathrm{~m}$ (Figs. 7, 12), and in the upper 

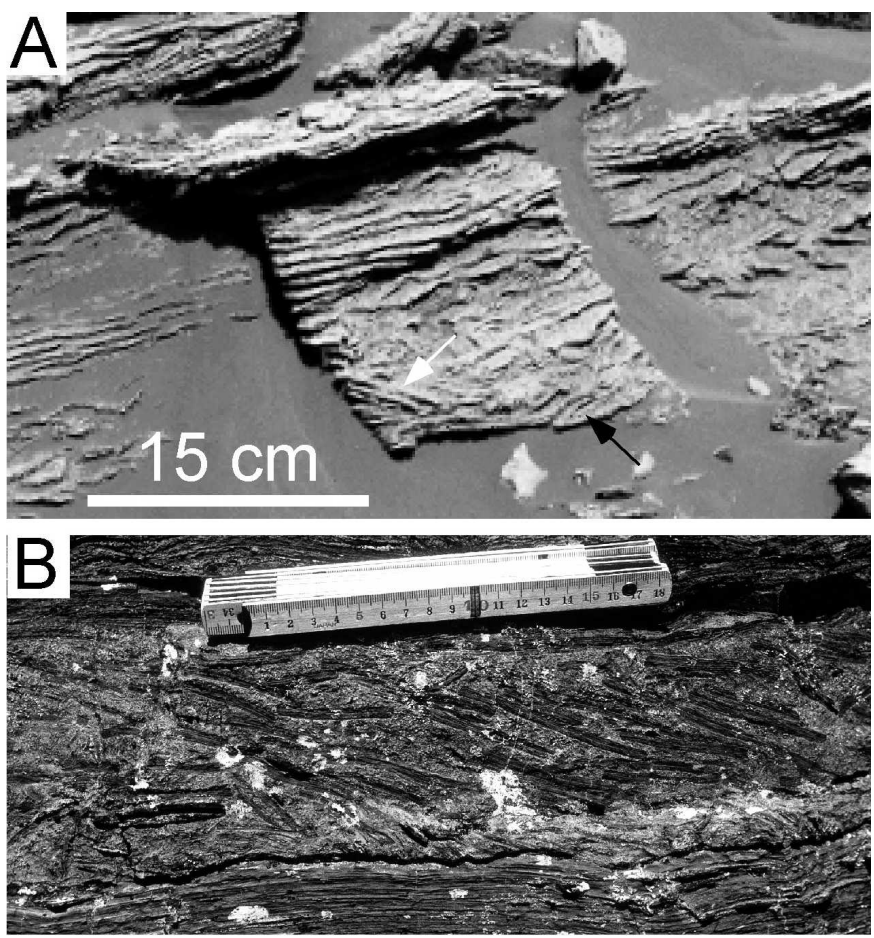

Fig. 11.-A) Close-up of the area with putative rip-up clasts indicated in Figure 8A. These rip-up clasts likely formed when the surface sediment became crusted over and was then later broken up, reworked, and deposited by a current. The clasts indicated by the white arrow appear to be imbricated. The clast indicated by the black arrow appears to have broken into at least two pieces. There may also be a few more clasts imbricated in the same direction as those mentioned above in the block to the right, although they are more poorly defined. B) Earth analog showing imbricated rip-up clasts from the Rocknest Formation (1.9 Ga), northern Canada. Scale is in centimeters

unit of Yavapai, between $2.25 \mathrm{~m}$ and $2.70 \mathrm{~m}$ (Figs. 13, 14). Palimpsest lamination in the mottled facies in the upper unit of Payson indicates that wavy lamination may have been the precursor stratification in this area as well. A large portion of the Olympia outcrop is also wavy-laminated (Fig. 6). Wavy-laminated strata may result from shallow scours backfilled with laminae that drape the scour surface, which could be caused by local turbulence, changes in wind speed, or fluctuations in surface wetness or sediment supply (Kocurek 1981).

Wavy lamination is characteristic of damp to wet interdune environments (Kocurek 1981). In a study of eolian sandstones, Hunter (1981) described wavy bedding deposited in wet interdune areas. He attributed relatively regular waviness to ripples (wave ripples, wind ripples, or subaqueous ripples), and he attributed less regular waviness to adhesionripple growth, current or wind scour, gas-bubble growth and escape, dewatering, and small-scale loading.

Given the evidence for migration of small-scale subaqueous ripples described above, it is also possible that the wavy lamination could have resulted from supercritically climbing ripples (i.e., ripples that climb at angles greater than the angle of the stoss slope). If true, this would imply that the flows were decelerating with high concentrations of suspended sediment.

\section{Flat-Laminated to Low-Angle-Stratified Sandstone}

Flat-laminated to low-angle cross-stratified strata typically display thin lamination that is geometrically arranged in bed sets showing low-angle truncations (less than $20^{\circ}$ ). This is in contrast to the cross-strata which form by migration of dune slip faces, which are usually tangential to their underlying bounding surfaces (Fryberger et al. 1979).

The thin lamination is likely the expression of alternating finer and coarser layers deposited during sediment transport in eolian environments where wind ripples migrate under conditions of bed accretion (Hunter 1977a). This type of facies probably represents translatent wind-ripple strata deposited on dune bottomset beds or in a sand sheet (Kocurek and Nielson 1986), where each individual lamina is formed by the translation of a single wind ripple. The ripples in this case were likely subcritically climbing, since these result in well-defined tabular lamination where cross-lamination is rarely seen. Low-angle cross-stratification can also form on the lee side of a dune, where the slope is lower than the angle of repose (such as on bottomset beds), and sand is deposited by grainfall (Hunter 1977b; Hunter 1981).

Much of the Yavapai outcrop appears to be composed of this facies. In the upper unit is an $\sim 2$-m-thick facies which appears to be planar- to low-angle stratified. The strata in this unit are $\sim 1-2 \mathrm{~cm}$ thick. Laminae produced by wind ripples on Earth are typically a few millimeters thick (Fryberger and Schenk 1988; Stolper et al. 2007); however, the strata in the Yavapai outcrop, which may have formed from the migration of wind ripples, are closer to $1-2 \mathrm{~cm}$ thick. Sands with a greater grain size range can produce ripples with a greater height, so this may imply that the ripples at Yavapai had a larger range of grain sizes (Bagnold 1941).

However, several other possible processes could have deposited the beds in the upper unit of Yavapai. One possibility is that we are not able to discern finer-scale (millimeter) laminae because of the resolution limits of the images, and so these $1-2 \mathrm{~cm}$ thick beds are actually bedsets of finerscale laminae. This is a likely explanation given that the smallest features in the images that we can discern at this distance from the outcrop are $\sim 8 \mathrm{~mm}$. It is also possible that the centimeter-scale stratification was formed by eolian grainflows. Grainflows occur on the foresets of dunes, so if the dunes had straight crestlines and if this is a view that is oblique or normal to transport, then it would show centimeter-scale planar

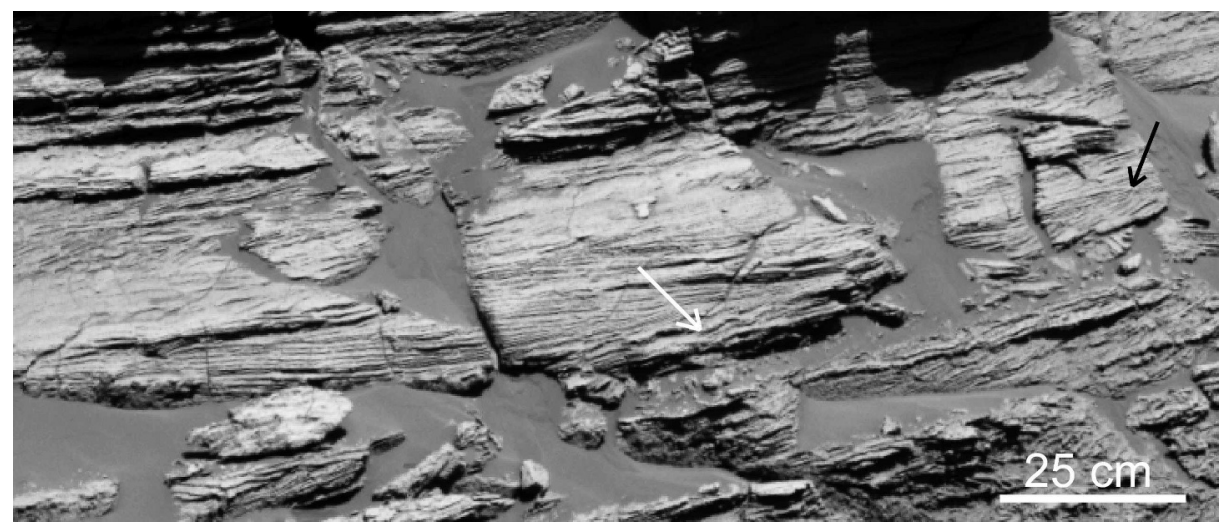

FIG. 12.-Wavy and low-angle stratification in the area of the Payson outcrop indicated in Figure 8A. Wavy lamination is indicated by the white arrow and low-angle stratification by the black arrow. 


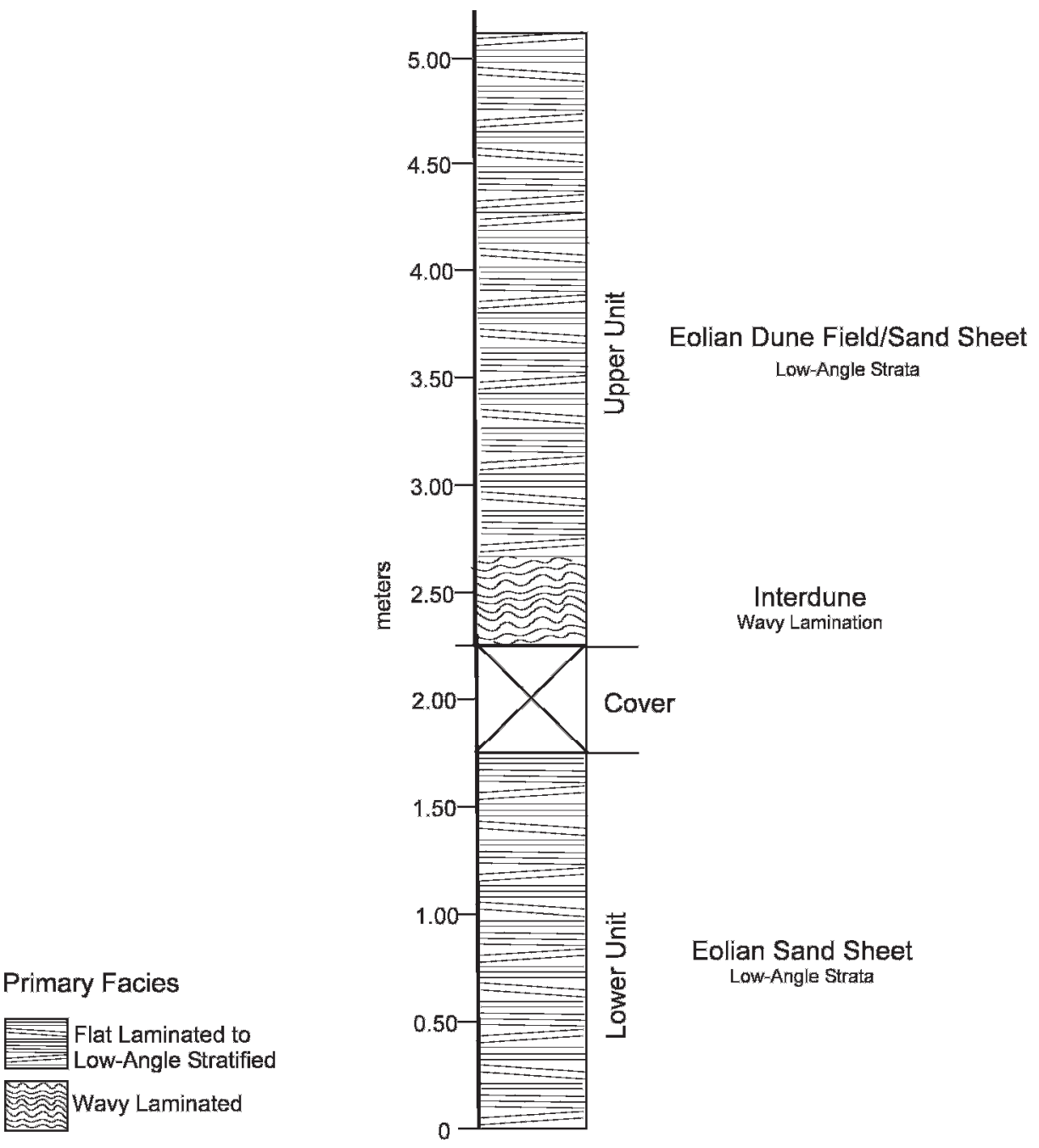

FIG. 13.-Stratigraphy of Yavapai. Two units in Yavapai are separated by an interval of soil cover. The lower unit is flat laminated to lowangle stratified and is interpreted to have been deposited as an eolian sand sheet. The upper unit can be subdivided into two facies. The lower facies is wavy-laminated and was likely deposited in an interdune area. The upper facies is flat laminated to low-angle stratified and was likely deposited in either an eolian dune field or a sand sheet. lamination. However, grainflows typically have a limited lateral extent and appear as lenses in a strike section as shown by Hunter (1977a, his fig. 8), but these lenses may not be visible given the low resolution of the images. They could also potentially be deposits of the upper flow regime of an aqueous flow, but this is less likely given the thickness $(\sim 2 \mathrm{~m})$ of this deposit. Planar-laminated deposits formed in the upper flow regime are often on the order of tens of centimeters thick (Langford and Bracken 1987; Bal and Lewis 1994), because they are limited by the difficulty of maintaining a constant flow without decelerating into a lower flow regime (Fig. 15). However, it is possible to stay in the upper-plane-bed regime and maintain high flow velocities for a long time at substantial flow depths, which can happen in fluvial environments, shallow marine environments, as well as in turbidity-current deposition in deep water. If the rate of downstream decrease in sediment transport rate is sufficiently great, a thick succession of planar-laminated sediment can be deposited. Another possibility is that these beds were formed by supercritically climbing wind ripples, which are also unlikely to persist over such long distances since they require high sediment aggradation rates or rapidly decreasing throughgoing sediment transport rates (Rubin and Hunter 1982).

\section{Trough Cross-Bedded Sandstone}

The middle unit of Payson is composed of fairly regular $\sim 3-4 \mathrm{~cm}$ thick cross-stratified bedsets, with shallow trough geometry (Figs. 2, 16). The cross-beds in each set dip in opposite directions. If an individual cross-bed is traced across the layer, it can be seen to form a trough with a wavelength of $\sim 1 \mathrm{~m}$. More of the cross-beds dip to the left than to the right; thus there is also a component of transport from right to left, which means that the outcrop face is oblique to the paleoflow direction.

These cross-strata likely represent the toes of larger sinuous-crested eolian dunes deposited during bedform migration. If a dune migrates at a subcritical rate of climb, only a portion of the foreset of the dune is preserved and sets of cross-strata are separated by erosional bounding surfaces (Kocurek 1991). This typically leads to preservation of only the basal portions of dunes in the rock record, and hence set thickness is only a fraction of the original bedform height (Rubin and Hunter 1982). Thus, the dunes that deposited these cross-strata were probably larger than $4 \mathrm{~cm}$.

\section{FACIES ASSOCIATIONS AND DEPOSITIONAL ENVIRONMENTS}

The facies observed at Erebus crater form three distinct facies associations which characterize a dune-interdune system. These facies associations are eolian dune, damp-wet interdune, and eolian sand sheet. Similar facies associations were described for the Burns formation in Endurance and Eagle craters (Grotzinger et al. 2005).

\section{Eolian Dune}

The eolian-dune facies association includes the trough cross-bedded facies in the middle unit at Payson (Fig. 7) and potentially the flat 


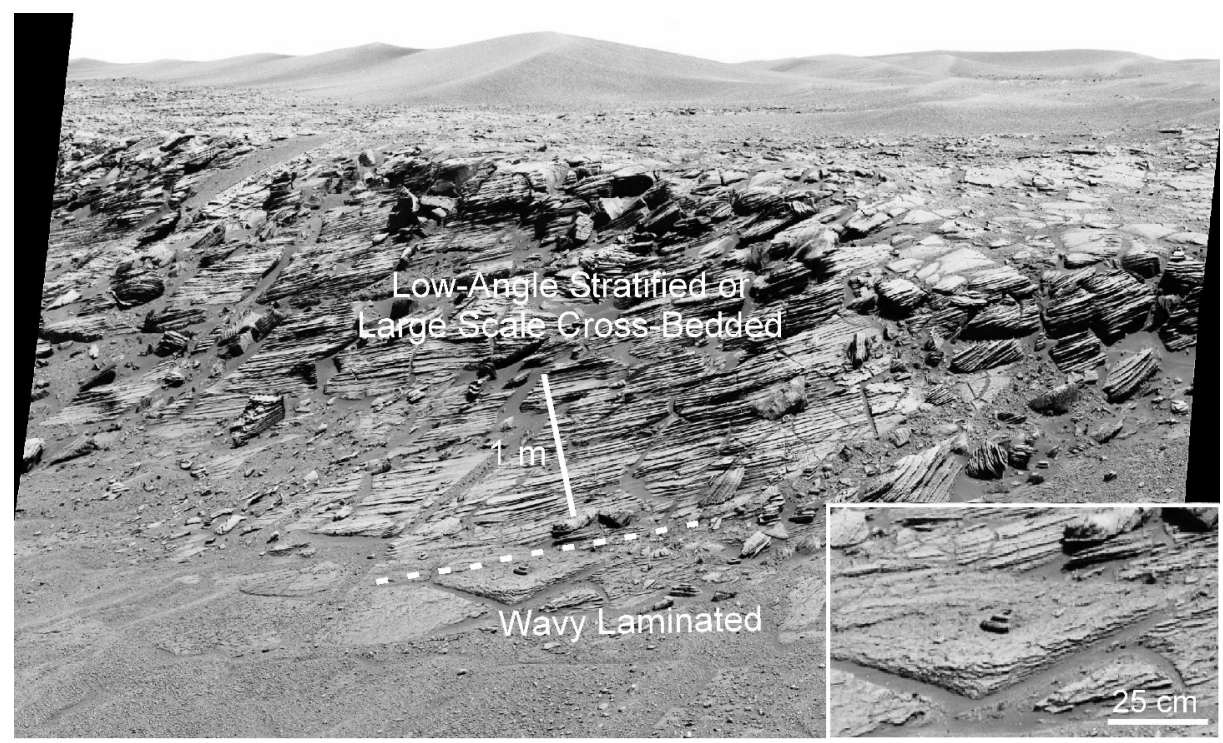

FIG. 14.-Yavapai upper unit. The lower facies is wavy laminated, and the upper facies is either low-angle stratified (rotated by deformation) or one-half of a large trough-shaped bedform. The dashed white line indicates the facies transition. The inset shows the wavy laminated facies up close. Pancam images acquired on sol 758 with the $430 \mathrm{~nm}$ filter.

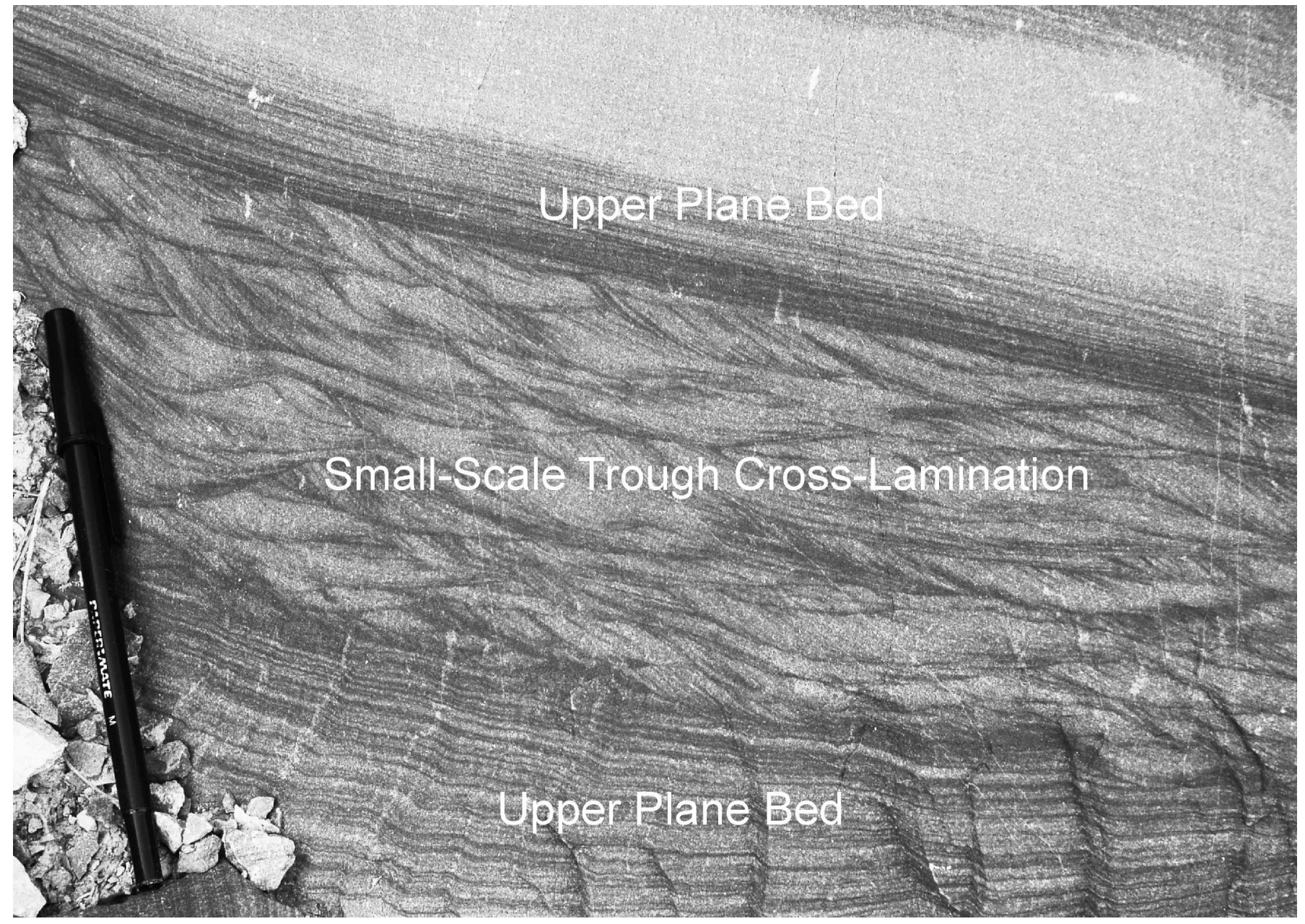

FIG. 15. - Upper-flow-regime plane beds pass into to lower flow-regime small-scale trough-cross-lamination in 1.4 Ga Mt Shields Formation, Belt Supergroup, Montana. The flows responsible for this lamination were formed in shallow channels. As the flow decelerates, it passes into small-scale trough cross-lamination. The top of the small-scale trough cross-laminated deposit was eroded away by the next event of high-velocity flow and upper-plane-bed deposition. Pen is $15 \mathrm{~cm}$ long. 


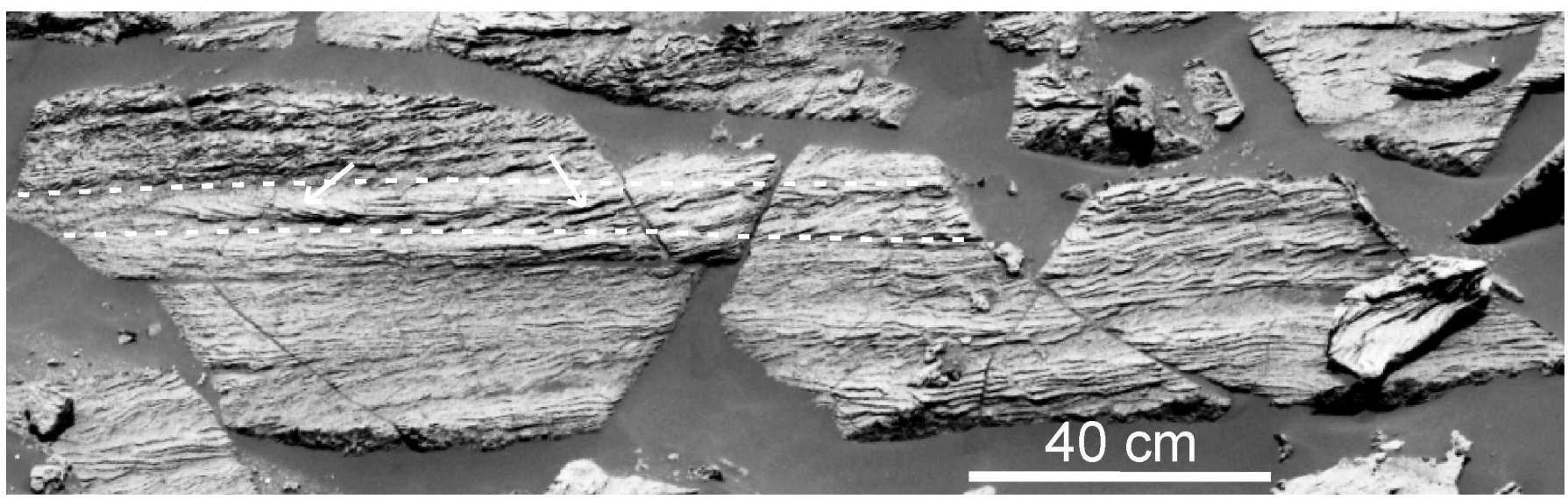

FIG. 16.-Close-up view of the area of trough cross-bedded sandstone shown in Figure 2A. The dashed white lines indicate a cross-bed set boundary, and the white arrows indicated the cross-beds in this layer. The cross-beds can be seen to be dipping in opposite directions, although there is a preponderance of dips to the left, suggesting a view cut obliquely to transport. If an individual cross-bed is traced across the layer, it can be seen to form a trough with a wavelength of $\sim 1 \mathrm{~m}$. Pancam image acquired on sol 749 with the $430 \mathrm{~nm}$ filter.

laminated to low-angle stratified facies of the upper unit of Yavapai, if this stratification is representative of two sides of large trough cross-beds (Fig. 4). These trough cross-beds are indicative of sediment transport by migrating sinuous-crested dunes. This suggests at least an episodically dry climate or a low water table due to other topographic effects in the region. The extent of the paleo-dune field is uncertain, but it was likely relatively widespread since similar facies were identified in Endurance crater $\sim 4 \mathrm{~km}$ away and layers of this formation appear to be laterally continuous as inferred from MOC and TES data.

\section{Eolian Sand Sheet}

There is a thin exposure of the eolian-sand sheet facies in the lower unit at Payson and it may be the dominant facies at Yavapai (Figs. 2, 14, 17). There are also exposures of the sand sheet facies at Olympia (Fig. 6).

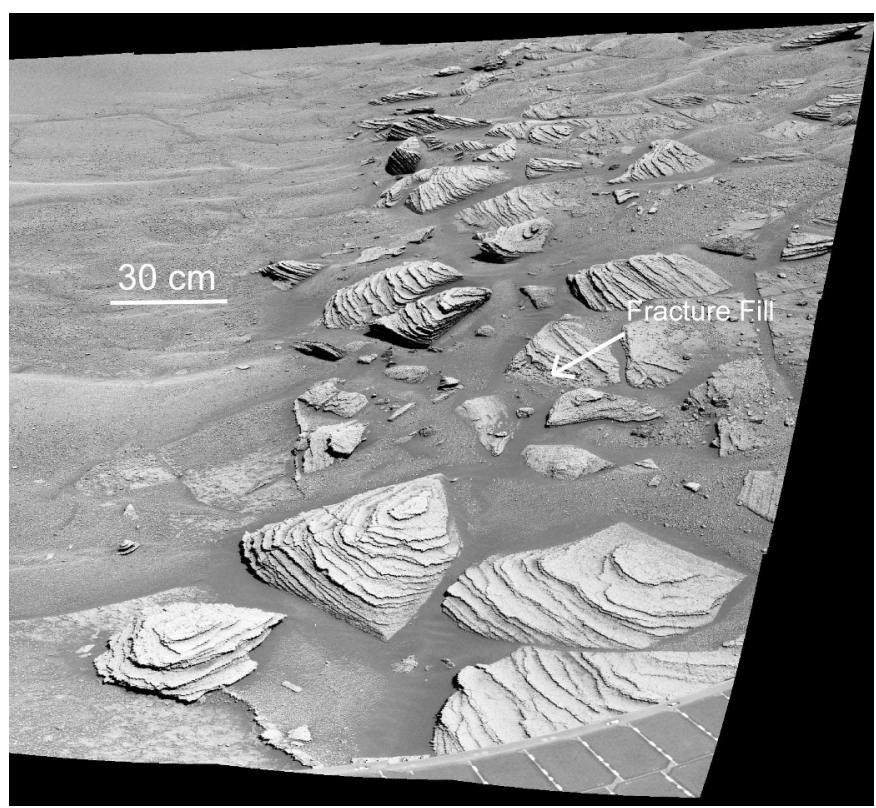

FIG. 17.-Yavapai lower unit. This unit is flat laminated to low-angle stratified and weathers to a rough appearance. The location of a fracture fill is marked Pancam images acquired on sol 758 with the $430 \mathrm{~nm}$ filter.
These associations are composed of flat-laminated to low-angle-stratified sandstone and consist largely of wind-ripple laminae. Sand sheet deposits are transitional facies between dune and interdune deposits and also often form on the boundaries of dune-interdune systems (Fryberger et al. 1979; Kocurek and Nielson 1986). They form from the accretion of wind-blown sand in areas where conditions are not suitable for the formation of dunes or where some factors inhibit the formation of dunes (Kocurek and Nielson 1986). Factors that favor sand sheet development are: (1) a high water table, (2) early cementation, (3) high sediment moisture content or wetting during floods, and (4) coarse-grained sediment (Kocurek and Nielson 1986). Instead of forming dunes under these conditions, these factors result in low, rolling, hummocky topography.

The thin lamination seen in sand sheet deposits is deposited by wind ripples by the saltation of sand. The low-angle discordances develop during the migration of low-relief mounds of sand, not by slip-face processes such as grainflows.

\section{Interdune}

An interdune depression is commonly enclosed or partly bounded by eolian dunes or sand sheets (Ahlbrandt and Fryberger 1981). Several of the facies in the Olympia and Payson outcrops, as well as the base of the upper unit of Yavapai, are indicative of a damp to wet interdune environment (Figs. 6, 7, 13). The association of small-scale trough crosslamination, wavy laminae, desiccation cracks, and rip-up clasts is indicative of a damp to wet interdune environment with episodic wetting and drying, which could result from minor fluctuations in the groundwater table (Mountney and Thompson 2002). Sedimentation in interdune depressions is enhanced by a high water table and early evaporitic cements, and since interdune deposits form in topographic depressions, they are selectively preserved (Hummel and Kocurek 1984). An interdune environment can be classified as "dry," "damp," "wet," or "evaporitic" on the basis of the abundance of water-induced processes (Kocurek 1981; Fryberger et al. 1983).

In a wet interdune environment, the water table is shallow, and the deposits are within the capillary fringe of the water table. Sedimentary structures typical of a wet interdune environment are small-scale trough cross-lamination, wavy lamination (Hunter 1981), contorted or syndepositionally deformed strata, and rip-up clasts (Fryberger et al. 1983). A damp interdune commonly exhibits contorted or syndepositionally deformed strata and adhesion structures caused by sand adhering to a damp surface (Kocurek 1981; Fryberger et al. 1983). A dry interdune 
consists mostly of wind-ripple strata and exists where the water table is relatively deep (Kocurek 1981; Fryberger et al. 1983).

The facies associations in the Olympia outcrop indicate a mainly wet interdune environment because of its multiple exposures of small-scale trough cross-lamination, wavy lamination, and synsedimentary deformed strata. The Payson outcrop is indicative of a damp-wet interdune because of its exposures of wavy lamination, possible rip-up clasts, and occasional small-scale trough cross-lamination. The thin exposure of wavy lamination at the base of the upper unit of Yavapai indicates a damp interdune environment.

\section{Olympia Outcrop Stratigraphy}

In attempting to develop a stratigraphy that allows correlation within outcrops as well as between outcrops, we are limited to consideration of physical attributes only, in particular the facies. Only one rock at Olympia was analyzed for its chemical and mineralogic composition, and none were analyzed at Payson and Yavapai. The analysis at Olympia of the rock "Ted" indicates that this rock is similar in composition to rocks analyzed at other localities visited by Opportunity (Knoll et al. 2008).

The Olympia outcrop was divided into several facies as discussed above, including planar to wavy-laminated sandstone and small-scale trough cross-laminated sandstone. Some rocks show penecontemporaneous sedimentary features including shrinkage cracks and soft-sediment deformation (Fig. 6). Several examples of small-scale trough crosslamination and shrinkage cracks at Erebus crater were previously described by Squyres et al. (2006) and Grotzinger et al. (2006). Some facies could be correlated between a few adjacent outcrop blocks, but there were no facies patterns that could be correlated across the Olympia outcrop due to their displacement and rotation.

\section{Payson Outcrop Stratigraphy}

Payson was divided into several facies (Figs. 2, 7), which are distinguished by their sedimentary structures, secondary diagenetic textures, and color. These facies are grouped into three units: a lower unit, a middle unit, and an upper unit. The lower unit is $\sim 1.25 \mathrm{~m}$ thick and is composed of three facies: a mottled facies, a wavy-laminated facies, and a low-angle-stratified facies. The mottled facies has a texture interpreted to be the result of recrystallization and grades laterally (from north to south) and vertically from strongly recrystallized, such that the original sedimentary structures cannot be distinguished, to less severely recrystallized, such that some primary structures can be identified. One structure that can be identified is the putative rip-up clasts. Figure $8 \mathrm{~A}$ shows the lateral variation within the mottled facies grading from the northernmost areas, where primary textures have been almost completely destroyed, to areas where the original stratification, including rip up clasts, are visible. This lateral variation in the recrystallization is a real effect and not an artifact of the limitations of the image resolution. The details of the textures are within the resolution limits for all described areas of the outcrop. This mottled facies is approximately $90 \mathrm{~cm}$ thick, and its upper contact is a scour surface. Above the mottled facies is a 20 $30 \mathrm{~cm}$ thick wavy laminated facies with rare sets of centimeter-scale trough cross-lamination (Figs. 2A, 7). A scour surface can be seen in this facies; its upper contact is also a truncation surface. The third facies in the lower unit of Payson is a 10-cm-thick low-angle-stratified facies whose top is a scour surface (Figs. 2A, 7).

The middle unit of Payson is composed entirely of a trough crossbedded facies. This unit is $1.2 \mathrm{~m}$ thick, and the troughs have meter-scale wavelengths (Figs. 2, 7, 16). Since trough cross-stratification is a way-up indicator, it implies that the rocks in the Payson outcrop are the right way up and not part of an overturned flap. Overturned flaps are part of the ejecta blankets of impact craters and are sections of pre-existing stratigraphy that are ejected from the crater and are preserved in detail, but inverted (Jones 1978).

The upper unit is $2.4 \mathrm{~m}$ thick and is characterized by a facies with a mottled texture interpreted to be the result of recrystallization with rare zones of centimeter-scale trough cross-lamination and rip up clasts. The boundary between the middle and upper units is gradational and is the result of diagenetic alteration obscuring the lamination (Fig. 2B).

The geomorphic rim that defines the top of the outcrop appears to be horizontal but is not a bedding plane, since the bedding can be seen cutting across the rim in some places (Fig. 2). The location of the rim varies between the middle and the upper unit. The geomorphic expression of the rim reflects differential lithification, probably the result of diagenesis that postdates deposition and deformation. This is consistent with the groundwater table rising above the tilted and buried layers. The groundwater table should be more or less horizontal, especially in porous sediments.

\section{Yavapai Outcrop Stratigraphy}

The lower unit of Yavapai is a planar-stratified to low-angle-stratified unit and is approximately $1.75 \mathrm{~m}$ thick (Figs. 13, 17). The contact between the lower and upper unit is obscured by a cover of soil (Fig. 3). The upper unit of Yavapai contains two facies (Figs. 13, 14). The lower facies is wavy laminated, and its contact with the upper facies is not clearly resolved because of the quality of the images and soil cover (Fig. 14 inset). The upper facies is thin bedded with several low-angle truncation surfaces. Because close-up images of Yavapai were not acquired, it is not possible to see the details of this outcrop. Since the upper facies is not resolved, we propose several possible interpretations based on its similarity to other similar-scale stratification at Meridiani: (1) The stratification is large-scale cross-bedding and the two different dip directions are the two sides of a large trough bedform (Fig. 4B). No structural deformation is necessary for this option. (2) The planar to lowangle stratification represents preservation of the basal foresets of migrating straight-crested dunes. The outcrop exposure is a view cut perpendicular to the transport direction. Later, the beds were deformed to acquire their present day dips (Fig. 4A). (3) The planar to low-angle stratification is the result of migrating hummocky low-amplitude bedforms in a sand sheet. The present day dips in this case are also due to later deformation. It is not possible to distinguish between these possibilities without higher-quality images or examination of additional outcrop exposures.

\section{DISCUSSION}

\section{Alternative Interpretations for Depositional Processes}

Base Surge.-Two alternative interpretations have been suggested which propose that the stratification observed at the Opportunity landing site was the result of base-surge processes, alternatively generated by volcanic (McCollom and Hynek 2005) or impact (Knauth et al. 2005) processes. However, the sedimentology of the Olympia, Payson, and Yavapai outcrops differs broadly from the attributes predicted by these interpretations. Pyroclastic surges are characterized by the following facies from a vent-proximal to vent-distal direction: decimeter- to meterscale supercritically climbing cross-stratification, massive deposits, and planar, centimeter-scale stratification (Wohletz and Sheridan 1979). Base surges also are commonly coarse-grained and have poor sorting over meter scales. Bomb sags are common. Desiccation cracks and imbricated rip-up clasts are not described.

No decimeter- to meter-scale supercritically climbing cross-strata were observed at Olympia, Payson, or Yavapai. Massive beds that might represent mass-flow deposits are also not observed. While a mottled and poorly stratified facies was observed, which might at first glance suggest a 


\section{Primary Facies} Damp to Wet: Subaqueous Ripple Cross-Stratified, Wavy Lamination, Soft-Sed Deformation

NII Synsedimentary Deformation/ III) Rip-Up Clasts

\section{Dry to Damp: Eolian} Sandsheet or Interdune

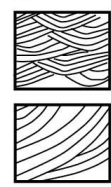

Dry: Trough Cross-Bedding

Dry: Large-Scale

Eolian Cross-Bedding

\section{Diagenetic Overprint}

\section{से} \%

Mottled and Recrystallized

.• Hematitic Concretions



Recrystallization in

Vadose-Phreatic Zone

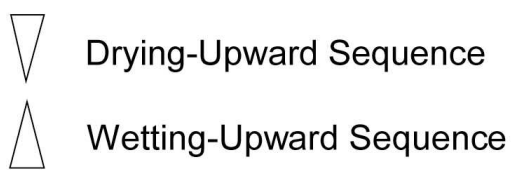

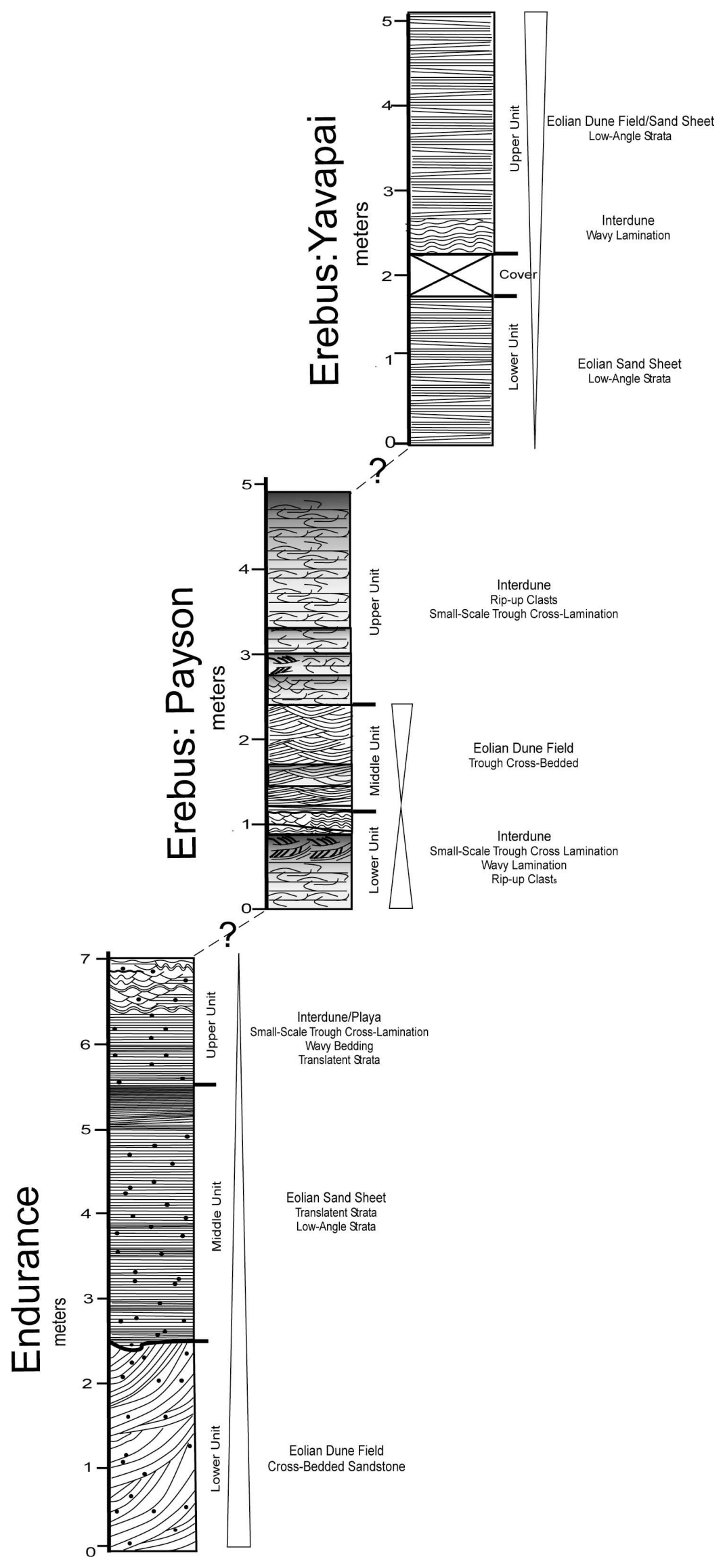


possibly massive facies, even this has palimpsest millimeter-scale lamination, which indicates that it was emplaced as a thinly-laminated deposit. Therefore, these beds were not deposited as mass flows, but rather as a result of traction-controlled transport. Their mottled appearance is interpreted to result from postdepositional recrystallization. Wavy lamination at the millimeter-scale and small-scale trough cross-lamination, as observed at Payson, has not been reported in surge deposits. Wavy bedding does occur in base-surge deposits, but it is an order of magnitude larger in scale (Branney and Kokelaar 2002). Planarlaminated facies are observed at Olympia, Payson, and Yavapai, and are found in both base-surge and dune-interdune deposits. No bomb sags were observed in any of the outcrops at Erebus crater (or in any other strata previously studied by Opportunity at Meridiani). The facies pattern at Erebus as a whole, given the lack of decimeter- to meter-scale supercritically climbing cross-strata and the presence of millimeter-scale wavy lamination and centimeter-scale trough cross-lamination, is more consistent with a dune-interdune environment than a base-surge deposit. This is further supported by the consistently fine-grained nature of the Meridiani deposits and their excellent sorting (Squyres et al. 2006). Finally, the possible desiccation cracks observed at Olympia and the imbricated rip-up clasts observed at Payson are most consistent with an eolian interdune environment.

Aqueous Deposition.-Another alternative interpretation for the Meridiani strata is that they were deposited predominantly during subaqueous sedimentation. This was considered briefly in Grotzinger et al. (2005). All of the types of stratification observed in the outcrops to date could form as a result of subaqueous sedimentation.

Small-scale trough cross-lamination is exceedingly rare in purely eolian deposits. However, trough cross-beds with wavelengths of $1 \mathrm{~m}$ and heights between 3-4 cm (as seen in the Payson outcrop) form by migrating sinuous-crested bedforms and develop in both eolian and subaqueous settings. The scale of these bedforms does not uniquely determine their origin. Also, since only the basal portions of the bedforms were preserved, the original bedform height was likely greater than $4 \mathrm{~cm}$. Subaqueous dunes typically have a height that is $10-40 \%$ of the flow depth (Leclair 2002), which implies, if these bedforms were produced subaqueously, that water flow depths exceeding $\sim 40 \mathrm{~cm}$ would have been attained.

More problematically, large-scale cross bedding, such as that observed in the lower unit of the Burns formation in Endurance crater, could represent large subaqueous dunes. Dunes of this type could form in fluvial bar forms (Miall 1992) or shallow marine, tidally generated bar forms (Dalrymple 1992). Bedsets of large scale cross-beds in Endurance crater range in height from $5 \mathrm{~cm}$ up to greater than $2.2 \mathrm{~m}$ (Grotzinger et al. 2005). Since bed thickness is typically only a small fraction $(\sim 10 \%)$ of the height of the bedform that deposited it, the dunes which deposited these cross-beds could have been many meters high (Rubin and Hunter 1982). This would require water flows that were even deeper (Leclair 2002), possibly on the order of 10 meters or greater. Since tidal currents on Mars should be only 5-10\% of terrestrial mean tides (de Pater and Lissauer 2001), it is unlikely that tidal currents on Mars would have been strong enough to generate these bedforms. Also, MOLA data indicate that Meridiani does not form a closed basin (Aharonson et al. 2001), so it would be difficult to contain a body of water deep enough to contain large subaqueous dunes. Nevertheless, it is possible that these large-scale bedforms were fluvial in origin. This would imply deep and strong flows of water in order to produce subaqueous dunes many meters in height.
With these significant flows, the water would be expected to channelize. While channels and inverted valleys have been found in Meridiani Planum, they are located at a lower stratigraphic level than the outcrops discussed here (Edgett 2005). Evidence for channels, such as levees or point bars (Miall 1992), has not been found by the rovers. Furthermore, grain size might be expected to locally coarsen within possible channel deposits. This has not been observed.

Low-angle to planar lamination could form as a result of sediment transport in high-velocity, upper-flow-regime subaqueous flows. However, the 1-2 m thick deposits of low-angle to planar lamination are unlikely to form subaqueously given the thickness of this deposit. In a search of the literature, 33 deposits of upper-flow-regime plane-bed lamination were found with a thickness less than a meter (Williams 1971; Shaw 1972; Schwartz 1982; Dardis 1985; Cheel and Middleton 1986; Langford and Bracken 1987; Røe 1987; Chakraborty and Bose 1992; Bal and Lewis 1994; Sohn et al. 1999; Plint and Wadsworth 2003); six deposits were found with a thickness between 1 and 2 meters (Shaw 1972; Røe 1987; Bal and Lewis 1994); and three deposits were found with a thickness of 2 meters or greater (Shaw 1972; Andteron 1976; Bristow 1993).

Wavy lamination can also form subaqueously from supercritically climbing ripples. The thicknesses of wavy lamination observed thus far are $\sim 20-30 \mathrm{~cm}$ thick, which could be formed by supercritically climbing ripples. If the wavy lamination was formed by supercritically climbing ripples, then the flow which deposited them would have had to maintain high sediment aggradation rates relative to the ripple migration rates (Ashley et al. 1982).

Considered individually, each of the structures discussed in this section can form subaqueously. However, considered collectively and also considering the lack of other key features, such as channels and a fine upper limit to grain-size variations, the most parsimonious interpretation is that they formed as the result of deposits in a dune-interdune environment.

Climate Cycles.-Sedimentary basins are sensitive to fluctuations in the climate, which can lead to variability in surface-water runoff and in the elevation of the water table (Brookfield 1977). These can affect sedimentation patterns and the extent of preservation of eolian strata. Strata in Erebus crater, like those in the Burns formation in Endurance crater, record the interaction between eolian and fluvial processes. Repeated cycles of relative water-table rise and fall in a dune-interdune system would be expected to form stacked deposits of dune-interdune facies (Grotzinger et al. 2005). The interactions between eolian and fluvial processes have been widely documented on Earth in both modern and ancient deposits, and these interactions can result in basin-wide dryingupward or wetting-upward sequences (Clemmensen et al. 1989; Langford 1989; Frederiksen et al. 1998; Scherer and Lavina 2005). Alternations in wet/dry deposition might also arise from non-climatic factors such as migration of discrete masses of sand through the depositional area. In this model, the land would be drier when topography and stratigraphy allow better drainage (e.g., more sand is present), and wetter when drainage is blocked or the water table is perched.

The Burns formation is interpreted to record eventual wetting of the surface related to a relative rise in the water table (Grotzinger et al. 2005). In contrast, Erebus crater strata may show an overall drying-upward trend through the stratigraphic section from the Olympia outcrop in the north, to the Payson and Yavapai outcrops to the south. Unfortunately, this interpretation is not certain since the upper facies of the Yavapai outcrop is not clearly resolved. However, if the upper facies of Yavapai is

$\leftarrow$

FIG. 18.- Stratigraphic columns from Endurance and Erebus craters shown in their likely stratigraphic relationship. Endurance crater shows a wetting-upward trend whereas Erebus crater shows a drying-upward trend. Together they may represent a full climate cycle. 
composed of eolian stratification, then the series of outcrops seen at Meridiani may represent a full climate cycle, evolving from dry to wet to dry (Fig. 18). This is consistent with the stacked set of dune-interdune facies predicted by investigation of the Burns formation at Endurance crater.

In potential terrestrial analogs, such cycles of alternating wetting/ drying-upward sequences are often interpreted as the result of orbitally driven climate fluctuations or, alternatively, as a result of tectonic processes (Scherer and Lavina 2005). On Earth, climate fluctuations and tectonic processes can impress the stratigraphic record in similar ways, because both can modify sediment supply, sand availability, fluvial and eolian transport capacity, and water-table position (Clemmensen et al. 1989; Scherer and Lavina 2005). On Mars, however, regional tectonic processes related to lithospheric plate motions can be discounted since Mars is a planet in which mantle convection occurs beneath a thick, strong and immobile lithosphere (O'Neill et al. 2007). Plate tectonics does not operate on Mars (Albarède and Blichert-Toft 2007), and so highfrequency episodic regional subsidence is not expected. This is regarded to have been the case as well during the late Noachian to early Hesperian when the Burns strata were deposited (Breuer and Spohn 2003). Finally, more localized tectonic processes such as faulting - which is widespread at other regions of Mars - can be discounted for the Meridiani region, where there is no evidence of faulting that may have contributed to localized, episodic subsidence.

Since tectonic processes can be discounted as a factor in controlling stratigraphic architecture in the Burns formation, climatic regulation provides a satisfactory alternative explanation. More arid climate periods would result in a relative fall of the water table and development of eolian dune and sand drift facies. During wet periods, the water table would rise, inhibiting formation of sand dunes and promoting sand sheet or interdune fluvial accumulations (Scherer and Lavina 2005). Modeling studies by Andrews-Hanna et al. (2007) predict that significant groundwater upwelling and evaporation should have occurred in Meridiani Planum. Thus, the Burns formation could have resulted from sustained groundwater upwelling, perhaps modulated by climatic overprinting of groundwater recharge or groundwater discharge (evaporation rate), or both.

Mars is a planet whose stratigraphic record may have been much more susceptible to climate forcing as compared to earth. One potential cause of these climate fluctuations is obliquity cycles, with the position of the water table rising or falling from changes from high to low obliquity. Obliquity-driven solar insolation is much stronger on Mars than on Earth (Head et al. 2006). While the current obliquity of Mars is $25^{\circ}$, the models predict that the obliquity has varied widely from its current low value. Over the last 4 Gyr the obliquity probably reached a high of $46^{\circ}$, but may have reached as high as $82^{\circ}$ (Head et al. 2006). Furthermore, whereas climate on Earth is strongly influenced by its large oceans, the likely absence of any major water bodies on Mars would have ensured a much more direct link between solar insolation and stratigraphic response. Recent analysis of stratigraphic thickness distributions in the Arabia region of Mars also suggests a link between climate and sedimentary accumulation (Lewis et al. 2008a).

\section{CONCLUSIONS}

The outcrop exposures at Erebus crater provide additional evidence that support the dune-interdune model and highlight the inconsistencies with the base-surge models proposed for the emplacement of the Burns formation at the Opportunity landing site in Meridiani Planum. There is evidence for the greater involvement of liquid water in the outcrop exposures of the Olympia outcrop than was observed in Eagle or Endurance craters. The Olympia outcrop likely formed in a wet interdune and sand sheet environment. The facies observed in the Payson outcrop, which is likely stratigraphically above the Olympia outcrop, indicate that it was deposited in a damp-wet interdune, sand sheet, and eolian-dune environment. The Yavapai outcrop, which is likely stratigraphically above the Payson outcrop, indicates that it was deposited in primarily a sand sheet environment and also potentially in an eolian-dune environment. These three outcrop exposures may indicate an overall drying-upward trend spanning the stratigraphic section from its base at the Olympia outcrop in the north to its top at the Yavapai outcrop in the south. This contrasts with the wetting-upward trend seen in Endurance and Eagle craters. Thus, the full series of outcrops studied by Opportunity may represent a full climatic cycle, evolving from dry to wet to dry conditions. Obliquity-driven climate cycles may be a more significant factor in the development of the stratigraphic record of Mars as compared to Earth.

\section{ACKNOWLEDGMENTS}

We gratefully acknowledge the entire Mars Exploration Rover science and engineering teams for making this investigation possible. We also thank Gary Kocurek, John Southard, and Steven Fryberger for their helpful comments.

\section{REFERENCES}

Aharonson, O., Zuber, M.T., and Rothman, D.H., 2001, Statistics of Mars topography from the Mars Orbiter Laser Altimeter: Slopes, correlations, and physical Models: Journal of Geophysical Research-Planets, v. 106, p. 23,723-23,735.

Ahlbrandt, T.S., and Fryberger, S.G., 1981, Sedimentary features and significance of interdune deposits, in Flores, R.M., ed., Recent and Ancient Non-Marine Depositional Environments: Models for Exploration, SEPM, Special Publication 31, p. 293-314.

Albarède, F., And Blichert-Toft, J., 2007, The split fate of the early Earth, Mars, Venus, and Moon: Comptes Rendus Geoscience, v. 339, p. 917-927.

Andrews-Hanna, J.C., Phillips, R.J., And Zuber, M.T., 2007, Meridiani Planum and the global hydrology of Mars: Nature, v. 446, p. 163-166.

Andteron, R., 1976, Tidal-shelf sedimentation: An example from the Scottish Dalradian: Sedimentology, v. 23, p. 429-458.

Arvidson, R.E., Seelos, F.P., Deal, K.S., Koeppen, W.C., Snider, N.O., Kieniewicz, J.M., Hynek, B.M., Mellon, M.T., And Garvin, J.B., 2003, Mantled and exhumed terrains in Terra Meridiani, Mars: Journal of Geophysical Research-Planets, v. 108, 8073 p., doi: 10.1029/2002JE001982.

Arvidson, R.E., Anderson, R.C., Bartlett, P., Bell, J.F., Christensen, P.R., Chu, P., Davis, K., Ehlmann, B.L., Golombek, M.P., Gorevan, S., Guiness, E.A., Haldemann, A.F.C., Herkenhoff, K.E., Landis, G., Li, R., Lindemann, R., Ming, D.W., Myrick, T., Parker, T., Richter, L., Seelos, F.P., Soderblom, L.A., Squyres, S.W., Sullivan, R.J., and Wilson, J., 2004, Localization and physical property experiments conducted by opportunity at Meridiani Planum: Science, v. 306, p. $1730-1733$.

Arvidson, R.E., Poulet, F., Morris, R.V., Bibring, J.P., Bell, J.F., Souyres, S.W Christensen, P.R., Bellucci, G., Gondet, B., Ehlmann, B.L., Farrand, W.H., Fergason, R.L., Golomber, M., Griffes, J.L., Grotzinger, J., Guiness, E.A., Herkenhoff, K.E., Johnson, J.R., Klingelhöfer, G., Langevin, Y., Ming, D. Seelos, K., Sullivan, R.J., Ward, J.G., Wiseman, S.M., and WolfF, M., 2006, Nature and origin of the hematite-bearing plains of Terra Meridiani based on analyses of orbital and Mars Exploration rover data sets: Journal of Geophysical ResearchPlanets, v. 111, E12S08, doi: 10.1029/2006JE002728.

Ashley, G.M., Southard, J.B., And Boothroyd, J.C., 1982, Deposition of climbingripple beds: a flume simulation: Sedimentology, v. 29, p. 67-79.

Bagnold, R.A., 1941. The Physics of Blown Sand and Desert Dunes: London, Chapman \& Hall, $265 \mathrm{p}$.

BaL, A., AND LewIS, D.W., 1994, A Cretaceous-early Tertiary macrotidal estuarinefluvial succession: Puponga Coal Measures in Whanganui Inlet, onshore Pakawau Sub-basin, northwest Nelson, New Zealand: New Zealand Journal of Geology and Geophysics, v. 37, 287 p.

Beales, F.W., 1972, Dolomitic mottling in Palliser (Devonian) limestone, Banff and Jasper National Parks, Alberta, in Carbonate Rocks I: Classifications-DolomiteDolomitization: American Association of Petroleum Geologists, Reprint Series no 4.

Branney, M.J., and Kokelaar, P., 2002, Pyroclastic density currents and the sedimentation of ignimbrites:, Geological Society of London Memoir 27, 143 p.

Breuer, D., AND Spohn, T., 2003, Early plate tectonics versus single-plate tectonics on Mars: Evidence from magnetic field history and crust evolution: Journal of Geophysical Research, v. 108, 5072 p., doi: 10.1029/2002JE001999.

BRISTOW, C.S., 1993, Sedimentary structures exposed in bar tops in the Brahmaputra River, Bangladesh: Geological Society of London, Special Publication, v. 75, p. 277-289. 
BRooKFIELD, M.E., 1977, Origin of bounding surfaces in ancient aeolian sandstones: Sedimentology, v. 24, p. 303-332

Bullen, S.B., And Sibley, D.F., 1984, Dolomite selectivity and mimetic replacement: Geology, v. 12, p. 655-658.

Chakraborty, C., and Bose, P.K., 1992, Ripple/dune to upper stage plane bed transition: some observations from the ancient record: Geological Journal, v. 27, p. 349-359.

Cheel, R.J., And Middleton, G.V., 1986, Horizontal laminae formed under upper flow regime plane bed conditions: Journal of Geology, v. 94, p. 489-504.

Clark, B.C., Morris, R.V., Mclennan, S.M., Gellert, R., Joliff, B., Knoll, A.H., Squyres, S.W., Lowenstein, T.K., Ming, D.W., Tosca, N.J., Yen, A., Christensen, P.R., Gorevan, S., Bruckner, J., Calvin, W., Dreibus, G., Farand, W., KlingelhöFer, G., Waenke, H., Zipfel, J., Bell, J.F., Grotzinger, J., McSween, H.Y., AND RIEDER, R., 2005, Chemistry and mineralogy of outcrops at Meridiani Planum: Earth and Planetary Science Letters, v. 240, p. 73-94.

Clemmensen, L.B., Olsen, H., and Blakey, R.C., 1989, Erg-margin deposits in the Lower Jurassic Moenave Formation, Wingate Sandstone, south Utah: Geological Society of America, Bulletin, v. 101, p. 759-773

Dalrymple, R.W., 1992, Tidal depositional systems, in Walker, R.G., and James, N.P., eds., Facies Models: Geological Society of Canada: St. John's, p. 195-218.

DARDIs, G.F., 1985, Genesis of late Pleistocene cross-valley moraine ridges, southcentral Ulster, Northern Ireland: Earth Surface Processes and Landforms, v. 10, p. 483-495.

De Pater, I., And Lissauer, J.J., 2001. Planetary Sciences: Cambridge, U.K., Cambridge University Press, $568 \mathrm{p}$.

Demicco, R.V., And Hardie, L., 1994, Sedimentary Structures and Early Diagenetic Features of Shallow Marine Carbonate Deposits: SEPM, Atlas, v. 1.

Edgett, K., 2005, The sedimentary rocks of Sinus Meridiani: Five key observations from data acquired by the Mars Global Surveyor and Mars Odyssey orbiters: Mars, v. 1, p. $5-58$.

EdgetT, K.S., And Malin, M.C., 2002, Martian sedimentary rock stratigraphy: Outcrops and interbedded craters of northwest Sinus Meridiani and southwest Arabia Terra: Geophysical Research Letters, v. 29, 2179 p., doi: 10.1029/ 2002 GL016515.

Fischer, A.G., 1964, The Lofer Cyclothems of the Alpine Triassic, in Merriam, D.F., ed., Symposium on Cyclic Sedimentation: Kansas State Geological Survey, Bulletin 169, p. 107-149.

Frederiksen, K.S., Clemmensen, L.B., and Lawaetz, H.S., 1998, Sequential architecture and cyclicity in Permian desert deposits, Brodick Beds, Arran, Scotland: Geological Society of London, Journal, v. 155, p. 677-683.

Fryberger, S.G., AND SchenK, C.J., 1988, Pin stripe lamination - a distinctive feature of modern and ancient eolian sediments: Sedimentary Geology, v. 55, p. 1-15.

Fryberger, S.G., Ahlbrandt, T.S., and Andrews, S., 1979, Origin, sedimentary features, and significance of low-angle eolian "sand sheet" deposits, Great Sand Dunes National Monument and vicinity, Colorado: Journal of Sedimentary Petrology, v. 49, p. 733-746.

Fryberger, S.G., Al-Sari, A.M., and Clishamp, T.J., 1983, Eolian dune, interdune, sand sheet and siliciclastic sabkha sediments of an offshore prograding sand sea, Dhahran Area, Saudi Arabia: American Association of Petroleum Geologists, Bulletin, v. 67, p. 280-312.

Grotzinger, J.P., Arvidson, R.E., Bell, J.F., Calvin, W., Clark, B.C., Fike, D.A. Golombek, M., Greeley, R., Haldemann, A., Herkenhoff, K.E., Jolliff, B.L., Knoll, A.H., Malin, M., Mclennan, S.M., Parker, T., Soderblom, L., Sohl-Dickstein, J.N., Souyres, S.W., Tosca, N.J., and Watters, W.A., 2005, Stratigraphy and sedimentology of a dry to wet eolian depositional system, Burns formation, Meridiani Planum, Mars: Earth and Planetary Science Letters, v. 240, p. $11-72$.

Grotzinger, J.P., Bell, J., Herkenhoff, K., Johnson, J., Knoll, A., McCartney, E., Mclennan, S., Metz, J., Moore, J., Seuyres, S., Sullivan, R., Aharonson, A., Arvidson, R., Joliff, B., Golombek, M., Lewis, K., Parker, T., and Soderblom, J., 2006, Sedimentary textures formed by aqueous processes, Erebus crater, Meridiani Planum, Mars: Geology, v. 34, p. 1085-1088.

Head, J.W., Marchant, D.R., Agnew, M.C., Fassett, C.I., and Kreslavsky, M.A., 2006, Extensive valley glacier deposits in the northern mid-latitudes of Mars: Evidence for late Amazonian obliquity-driven climate change: Earth and Planetary Science Letters, v. 241, p. 663-671.

Hummel, G., And Kocurek, G., 1984, Interdune areas of the back-island dune field, North Padre Island, Texas: Sedimentary Geology, v. 39, p. 1-26.

Hunter, R.E., 1977a, Basic types of stratification in small eolian dunes: Sedimentology, v. 24 , p. $361-387$.

HunTER, R.E., 1977b, Terminology of cross-stratified sedimentary layers and climbingripple structures: Journal of Sedimentary Petrology, v. 47, p. 697-706.

Hunter, R.E., 1981, Stratification styles in eolian sandstones: some Pennsylvanian to Jurassic examples from the western interior U.S.A., in Ethridge, F.G., and Flores, R.M., eds., Recent and Ancient Nonmarine Depositional Environments: Models for Exploration, SEPM, Special Publication 31, p. 315-329.

HyNEK, B.M., 2004, Implications for hydrologic processes on Mars from extensive bedrock outcrops throughout Terra Meridiani: Nature, v. 431, p. 156-159.

Jerolmack, D.J., Mohrig, D., Grotzinger, J.P., Fike, D.A., and Watters, W.A., 2006, Spatial grain size sorting in eolian ripples and estimation of wind conditions on planetary surfaces: Application to Meridiani Planum, Mars: Journal of Geophysical Research-Planets, v. 111, E12S02 p., doi: 10.1029/2005JE002544.
Johnson, K.S., 2005, Subsidence hazards due to evaporite dissolution in the United States: Environmental Geology, v. 48, p. 395-409.

JoNES, G.H.S., 1978, Coherently overturned flaps surrounding craters: Nature, v. 273, p. 211-213.

KNauth, L.P., Burt, D.M., and Wohletz, K.H., 2005, Impact origin of sediments at the Opportunity landing site on Mars: Nature, v. 438, p. 1123-1128.

Knoll, A., Joliff, B., Farrand, W., Bell, J., Clark, B., Gellert, R., Golombek, M. Grotzinger, J., Herkenhoff, K., Johnson, J., McLennan, S., Morris, R., Squyres, S., Sullivan, R., Tosca, N., Yen, A., and Learner, Z., 2008, Veneers, rinds, and fracture fills: relatively late alteration of sedimentary rocks at Meridiani Planum, Mars: Journal of Geophysical Research, v. 113, E06S16, doi: 10.1029/ 2007JE002949.

KocureK, G., 1981, Significance of interdune deposits and bounding surfaces in aeolian dune sands: Sedimentology, v. 28, p. 753-780.

KocureK, G., 1991, Interpretation of ancient eolian sand dunes: Annual Review of Earth and Planetary Sciences, v. 19, p. 43-75.

Kocurek, G., And Nielson, J., 1986, Conditions favourable for the formation of warmclimate aeolian sand sheets: Sedimentology, v. 33, p. 795-816.

LANGFORD, R.P., 1989, Fluvial-aeolian interactions part 1, modern systems: Sedimentology, v. 36, p. 1023-1035.

LANGFord, R., AND Bracken, B., 1987, Medano Creek, Colorado, a model for upper flow-regime fluvial deposition: Journal of Sedimentary Petrology, v. 57, p. 863-870.

LECLAIR, S.F., 2002, Preservation of cross-strata due to the migration of subaqueous dunes: an experimental investigation: Sedimentology, v. 49, p. 1157-1180.

Lewis, K.W., Aharonson, O., Grotzinger, J.P., Kirk, R.L., McEwen, A.S., and Suer, T.A., 2008a, Quasi-periodic bedding in the sedimentary rock record of Mars: Science, v. 322 .

Lewis, K.W., Aharonson, O., Grotzinger, J.P., and Squyres, S.W., 2008b, Structure and stratigraphy of Home Plate from the Spirit Mars Exploration Rover: Journal of Geophysical Research, v. 113, E12S36, doi: 10.1029/2007JE003025.

McCollom, T.M., AND HyneK, B.M., 2005, A volcanic environment for bedrock diagenesis at Meridiani Planum on Mars: Nature, v. 438, p. 1129-1131.

Mclennan, S.M., Bell, J.F., Calvin, W.M., Christensen, P.R., Clark, B.C., De Souza, P.A., Farmer, J., Farrand, W.H., Fike, D.A., Gellert, R., Ghosh, A., Glotch, T.D., Grotzinger, J.P., Hahn, B., Herkenhoff, K.E., Hurowitz, J.A., Johnson, J.R., Johnson, S.S., Jolliff, B., KlingelhöFer, G., Knoll, A.H., Learner, Z., Malin, M.C., McSween, H.Y., Pocock, J., Ruff, S.W., Soderblom, L.A., Squyres, S.W., Tosca, N.J., Watters, W.A., Wyatt, M.B., and Yen, A., 2005 , Provenance and diagenesis of the evaporite-bearing Burns formation, Meridiani Planum, Mars: Earth and Planetary Science Letters, v. 240, p. 95-121.

Melosh, H.J., 1989. Impact Cratering: A Geologic Process: Oxford Monographs on Geology and Geophysics: New York, Oxford University Press, 245 p.

Miall, A.D., 1992, Alluvial deposits, in Walker, R.G., and James, N.P., eds., Facies Models: Geological Society of Canada: St. John's, p. 119-142.

Mountney, N.P., AND Thompson, D.B., 2002, Stratigraphic evolution and preservation of aeolian dune and damp/wet interdune strata: an example from the Triassic Helsby Sandstone Formation, Cheshire Basin, UK: Sedimentology, v. 49, p. 805-833.

O'Neill, C., Jellinek, A.M., And Lenardic, A., 2007, Conditions for the onset of plate tectonics on terrestrial planets and moons: Earth and Planetary Science Letters, v. 261, p. $20-32$.

Plint, A.G., AND Wadsworth, J.A., 2003, Sedimentology and palaeogeomorphology of four large valley systems incising delta plains, western Canada Foreland Basin: implications for mid-Cretaceous sea-level changes: Sedimentology, v. 50, p. $1147-1186$.

RøE, S.-L., 1987, Cross-strata and bedforms of probable transitional dune to upperstage plane-bed origin from a Late Precambrian fluvial sandstone, northern Norway: Sedimentology, v. 34, p. 89-101.

Rubin, D., 1987, Cross-Bedding, Bedforms, and Paleocurrents:, SEPM, Concepts in Sedimentology and Paleontology, 1, $187 \mathrm{p}$

Rubin, D.M., and Hunter, R.E., 1982, Bedform climbing in theory and nature: Sedimentology, v. 29, p. 121-138.

Scherer, C.M.S., And LAvina, E.L.C., 2005, Sedimentary cycles and facies architecture of aeolian-fluvial strata of the Upper Jurassic Guara Formation, southern Brazil Sedimentology, v. 52, p. 1323-1341.

SCHWARTZ, R.K., 1982, Bedform and stratigraphic characteristics of some modern smallscale washover sand bodies: Sedimentology, v. 29, p. 835-849.

SHaW, J., 1972, Sedimentation in the ice-contact environment, with examples from Shropshire (England): Sedimentology, v. 18, p. 23-62.

Sohn, Y.K., Rhee, C.W., And Kim, B.C., 1999, Debris flow and hyperconcentrated flood-flow deposits in an alluvial fan, northwestern part of the Cretaceous Yongdong Basin, central Korea: Journal of Geology, v. 107, p. 111-132.

Squyres, S.W., Grotzinger, J.P., Arvidson, R.E., Bell, J.F., Calvin, W., Christensen, P.R., Clark, B.C., Crisp, J.A., Farrand, W.H., Herkenhoff, K.E., Johnson, J.R., KlingelhöFer, G., Knoll, A.H., McLennan, S.M., McSween, H.Y., Morris, R.V., Rice, J.W., Rieder, R., And Soderblom, L.A., 2004, In situ evidence for an ancient aqueous environment at Meridiani Planum, Mars: Science, v. 306, p. $1709-1714$.

Squyres, S.W., Knoll, A.H., Arvidson, R.E., Clark, B.C., Grotzinger, J.P., Jolliff, B.L., Mclennan, S.M., Tosca, N., Bell, J.F., Calvin, W.M., Farrand, W.H., Glotch, T.D., Golombek, M.P., Herkenhoff, K.E., Johnson, J.R., Klingelhöfer, G., McSween, H.Y., And Yen, A.S., 2006, Two years at Meridiani Planum: Results from the Opportunity Rover: Science, v. 313, p. 1403-1407. 
Squyres, S., Aharonson, A., Clark, B., Cohen, B.A., Crumpler, L., De Souza, P.A., Farrand, W.H., Gellert, R., Grant, J., Grotzinger, J.P., Haldemann, A.F.C., Johnson, J.R., Klingelhöfer, G., Lewis, K., Li, R., McCoy, T., McEwen, A.S. McSween, H.Y., Ming, D.W., Moore, J.M., Morris, R.V., Parker, T.J., Rice, J.W. Ruff, S.W., Schmidt, M., Schröder, C., Soderblom, L.A., And Yen, A., 2007, Mars Exploration Rover Results at Home Plate in Gusev Crater: Science, v. 316, p 738-742.

Stolper, D., Kennedy, M., And Grotzinger, J., 2007, Scale of lamination in sedimentary rocks as a guide to depositional process on Mars (Abstract): Geological Society of America, Abstracts with Programs, v. 396, 367 p.

Tosca, N.J., McLennan, S.M., Clark, B.C., Grotzinger, J.P., Hurowitz, J.A., Knoll, A.H., Schröder, C., ANd SquYres, S.W., 2005, Geochemical modeling of evaporation processes on Mars: Insight from the sedimentary record at Meridiani Planum: Earth and Planetary Science Letters, v. 240, p. 122-148.
Tosca, N., Knoll, A., And McLennan, S., 2008, Water activity and the challenge for life on early Mars: Science, v. 320, p. 1204-1207.

Williams, G.E., 1971, Flood deposits of the sand-bed ephemeral streams of central Australia: Sedimentology, v. 17, p. 1-40.

Winston, D., 1978, Fluvial systems of the Precambrian Belt Supergroup, Montana and Idaho, U.S.A., in Miall, A.D., ed., Fluvial Sedimentology: Canadian Society of Petroleum Geologists, Memoir 5, p. 343-359.

Wohletz, K.H., and Sheridan, M.F., 1979, Model of pyroclastic surge: Geological Society of America, Special Paper, v. 180, p. 177-194

Received 30 January 2008; accepted 25 August 2008. 